Article

\title{
Impacts of Social Innovation on Spatiality in Mountain-Lowland Relationships - Trajectories of Two Swiss Regional Initiatives in the Context of New Policy Regimes
}

\author{
Manfred Perlik
}

check for updates

Citation: Perlik, M. Impacts of Social Innovation on Spatiality in Mountain-Lowland Relationships Trajectories of Two Swiss Regional Initiatives in the Context of New Policy Regimes. Sustainability 2021 13, 3823. https:// doi.org/10.3390/su13073823

Academic Editors: Laura Secco,

Elisa Ravazzoli, Elena Górriz Mifsud and Elena Pisani

Received: 31 December 2020

Accepted: 23 March 2021

Published: 31 March 2021

Publisher's Note: MDPI stays neutral with regard to jurisdictional claims in published maps and institutional affiliations.

Copyright: (C) 2021 by the author. Licensee MDPI, Basel, Switzerland. This article is an open access article distributed under the terms and conditions of the Creative Commons Attribution (CC BY) license (https:// creativecommons.org/licenses/by/ $4.0 /)$.
Centre for Development and Environment, University of Bern, Mittelstrasse 43, 3012 Bern, Switzerland; manfred.perlik@unibe.ch

\begin{abstract}
This article places the topic of "social innovation" in the context of the paradigm shift of the 1980s. This shift from Fordism to post-Fordism has led to a weakening of the model of the European welfare state. Social innovation has become an instrument to promote regional self-responsibility and entrepreneurial activity by local authorities. The concept of social innovation has become widespread among various disciplines and controversially used by them. Referring to regional and corporate success stories based on the commitment of grassroots movements and civil society has its shortcomings, as the new spatiality regimes show increasing disparities. The article shows the different lines of conflict in the discussion about social innovations and makes suggestions for the specification and delimitation of the concept. Using two case studies on social innovations from mountain regions of Switzerland, based on standardized interviews, including the results of a social network analysis, the article distinguishes between adaptive and transformative social innovations. The adaptive social innovations analysed did not result in changing the inferior position of the regions; however, they prevented even greater destabilization by mobilizing the dynamic actors in the valley to work together. This is helpful for ensuring that the urban majority continues to show solidarity with the population in rural and mountain areas. The constructive interaction between public, private, and civil society institutions is seen as the key factor of social innovation in the European peripheral areas to which most mountain areas belong.
\end{abstract}

Keywords: impacts of social innovation; transformative social innovation; post-Fordist regime change; urban-rural linkages in mountain areas; European mountain areas

\section{Introduction: The Ambiguous Character of SI}

In the past decade, the term social innovation (SI) has become popular. It is associated with the hope to solve regional disparities and ecological crises; this is especially true in mountain regions, where the two issues are interconnected. Both are social fields whose development paths (trajectories) are driven by the interactions of actors residing and working in the territory. Due to the great expectations, the interpretation and scope of the term have expanded, too. Various disciplines from sociology to business administration are now dealing with it, so it is necessary to narrow down this umbrella term and define it for each issue. A helpful attempt at delimitation is the division of SI into "process, outcomes and impacts" [1]. A further specification enables us to distinguish between adaptive and transformative SI; the former could be characterised as performance-related, the latter as a deeper change in institutional regimes, or-applied to questions of regional development-as changes in spatiality. Due to different expectations from its proponents (researchers and practitioners), but also due to its double functions in outcomes (economic performance and sharing of power), the concept of SI proves to be highly ambivalent. This concerns the single terms "innovation" (what is really new?) and "social" (what concerns societal thinking, what concerns group egoisms?) as well as its combination (what is the difference in terms of other innovations, e.g., economic or technological?)Social innovation 
is a question of scale in space and time, and therefore a normative question. We have to decide whether a social change is an innovation when it is new in one country but already established by its neighbours (e.g., in the SIMRA project, the Greek partners analysed a fishery cooperative as a social innovation. In Europe, cooperatives are widespread; in German-speaking countries, they have even reached the status of nationwide companies. In Greece, however they were in large parts of society discredited for historical reasons and therefore not popular up to then). Furthermore, it is not clear to which former state of social relationships SI should refer (i.e., to which regime of accumulation and governance), which kind of progress it represents, and for whom it is meant (beneficiaries and losers).

We may understand the term "social" in two different ways. In the sense of "societal", SI focusses on the impact on all stakeholders of a given society. It promises a renewal of relationships between individuals or groups of actors in the sense of their improvement, which implies that existing disparities and societal cleavages are reduced and previously socially disadvantaged groups gain more influence. In terms of society as a whole, this would mean that this is not a zero-sum game (in which one dominant actor group is simply replaced by another), but a qualitative change in social relationships towards greater inclusion-in short, a transformative view. However, in recent years, we have seen steps in the other direction, resulting in emphasising differences in identity or regional egoism [2] and separatism. Is this an innovation? The example shows that SI needs a theoretical debate and more context knowledge to estimate its potential.

On the other hand, we may understand the term "social" in the sense of a wage earner relationship (rapport salarial, Lohnverhältnis). In this sense, SI focusses on the outcomes on the directly involved actors. This implies an increase in productivity through a more efficient use of labour (especially volunteer labour), the creation of new service offers, and thus increased regional competitiveness. In this case, social innovation means "creative destruction" in the sense of Schumpeter [3] and leaves behind innovation winners as well as innovation losers. It is social engineering without touching the foundations of existing disparities-in short, an adaptive view. Social engineering is problematic when applied affirmatively, for example to optimize value chains by better human resources management or by positioning a new product. Examples are a fast-food chain in South Africa [4] or the joint venture of the dairy food producer Danone with Nobel Prize winner Muhamad Yunus for a new lifestyle yoghurt [5]. These examples are in fact economic innovations and seem not of relevance for regional issues. However, in the frame of an increased competition of regions on territorial policies, this understanding should be treated as well, however in a critical approach.

The aim of this article is to put both interpretations in the context of their emergence in regional development and regional policies since the 1980s and to describe the impact of SI on the territorial adaptability to withstand regional decline. This was done by quantitative and qualitative analysis in two regions of the Swiss mountain area, which were investigated in depth in the SIMRA project (Social Innovation in Marginalised Rural Areas, a European Union-funded project under the Horizon Research and Innovation Programme). The discussion argues for a critical definition of the term. Furthermore, the potentials and limits of SI are considered and we discuss the transferability.

\section{Social Innovation as a Creator of Spatiality}

\subsection{The Paradigm Shift in Accumulation and Distribution with Its Territorial Implications}

When considering today's debate on SI in European mountainous areas, it is important to refer back to the initial situation after the Second World War. The European reconstruction was accompanied with outmigration from mountainous areas. The welfare state expanded in these years of economic miracle, called the Fordist period, which combined industrial mass production and mass consumption. In territorial issues, welfare state meant regional policies. They came into effect at the beginning of the 1970s. Too late, as with the 1973 oil crisis, the heyday of Fordism was already over, resulting in new paradigms of value adding and wealth distribution, thus creating a new spatiality between town and 
countryside. This paradigm shift took effect in the 1980s and provoked the devaluation of existing forms of production (and the associated social relationships), as well as the devaluation of social and territorial equality. It was associated with the renaissance of cities at the expense of peripheral areas. Those that lose inhabitants and jobs also lose-due to higher costs per inhabitant - the services newly created in the Fordist growth years, like bank offices, schools, swimming pools [6].

In the 1980s, "creative destruction" became the underlying concept for the regime change to offer-oriented development strategies, i.e., to generate temporary disproportional returns on investment by disrupting existing technologies, products or institutional regulations $[7,8]$. For regional development, this meant a regime change from policies of equal development to entrepreneurial competition and self-responsibility of regions-or, in other words, a new spatiality [9], which means a new relationship between regions, their production systems, and their social actors. If we accept calling this change in spatiality in the 1980s a social innovation, then we have to decide what to call today's initiatives that are trying to adapt to this break. Moreover, the question arises: was the disruptive paradigm change of the 1980s real a social innovation? Is it a social innovation in spatiality to counter the further dismantling of these private and public services with voluntary work and charitable fundraising? Focussing on the post-war period, it was, as a disruption, certainly an innovation; focussing on long-term development since the 19th century, it was certainly not. The qualification depends on the specific interests of the social actors-the winners and the losers. It is a question of scale and interests.

\subsection{Adaptive Versus Transformative SI}

The discussion about what is innovation and what is backward in a progress-oriented, emancipatory approach is not new. Today, nobody would call a gender-specialized division of labour a social innovation, even if it raised the GDP. Consequently, to evaluate an SI, a given society has to negotiate beneficiaries and losers. If we do not have clear criteria on this, all the global disruptions of the societal and political milieus of the last decade, grasped as a strategy of the disadvantaged to make their voices heard and fuelling their hopes for future wellbeing at the expense of others $[10,11]$, would have to be called an SI.

Whichever approach of definition of SI one prefers, it should involve a minimum of shared social standards and should adhere to the principles of sustainable development on a global scale, e.g., the United Nations SDGs [12], as a least common denominator. SI must deliver-beyond its direct outcomes for the innovators-a surplus of positive impacts for society. The SIMRA project expressed this in its definition with the term "societal well-being" (" ... the reconfiguring of social practices, in response to societal challenges, which seeks to enhance outcomes on societal well-being and necessarily includes the engagement of civil society actors"). The focus should be on the efforts of collective action to stabilise and further develop as a long-term impact the existing settlement structures and production systems through new forms of cooperation (within and across existing milieu boundaries). Less attention should be given to the concrete outcomes as they are mainly part of economic dynamics and practices. Of particular interest are new forms of solidarity economy as alternatives to the traditional private economy and an active civil society that supports the public services with constructive criticism. In many cases, early activism in terms of civic action will be a catalyst for professionalising, from which either the local private or the public institutions will benefit (and the social initiative dissolves). In any case, the relationship between the institutions becomes newly balanced, and, in the positive case, the society will stabilised.

However, we do not expect that individual initiatives alone could develop power to dissolve existing asymmetries between mountainous areas and lowland metropolitan regions, i.e., to create a new spatiality regime. Local initiatives will mostly be limited in character; they can help to prevent the widening of existing disparities. In this rather defensive guise, we can describe them as an adaptation [13] or "adaptive SI". However, they can-by exchanging and joining larger networks—become "transformative SIs" (as 
is the case with the food security/food autonomy movement). To be peripheral does not mean necessarily being peripheral for ever. A spreading movement of "adaptive" initiatives may finally turn into transformation [14]. A selection of SI examples fulfilling these aspirations is shown in Table A1 (Appendix A), not distinguishing between adaptive and transformative.

In the case of mountain development, one should expect transformative SI to help with the creation of new environmental and social standards. Transformative SI should aim at a new spatiality against the current spatial regime, characterized by increasing functional disparities at all scales. It includes also questioning the logics of permanent growth [15]. A new spatiality means decreasing not only the hierarchy between lowlands and mountainous areas but also the territorial cleavage between the global North and South, the source of a huge transfer of capital around the globe, generating intercontinental migration flows. In this sense, the welcome initiatives hosting refugees that emerged in many alpine municipalities can be clearly named transformative SI in that they can help counteract regional and Eurocentric egoism [16].

There is a huge literature on SI meanwhile. We can distinct two divergent approaches. The Anglo-Saxon approach is rather outcome-oriented and refers rather to entrepreneurial and regional competitiveness. It involves the rupture of existing institutional arrangements in order to achieve more efficient organisation of production. This may concern the delivery of public services to peripheral regions or the promotion of regional entrepreneurship, e.g., [17-21]. The French-continental approach is rather impact-oriented in its transformative understanding, aiming at social progress beyond the logics of regional competition to overcome the growth paradigm, and to create a new spatiality beyond the polarizing regime changes of the 1980s, e.g., [22-36].

\section{Rationale and Methods}

The data underlying this paper are based on the semi-structured interviews which were undertaken in the frame of the SIMRA project in Val Lumnezia (Grisons) and Canton of Neuchâtel (with the focus on Val-de-Travers), see Figure 1 and Table 1. The interviews in focus groups and with individuals were carried out between May 2018 and January 2019 as ex-post evaluations of two SI initiatives which started in the 1980s (Lumnezia) or 2000s (Neuchâtel). The interviews included the completion of a standardized questionnaire [37] and the generation of a matrix of social relations among the initiative members for a social network analysis (SNA) during three time spans of the innovative period. The SNA serves as a tool to measure the institutional thickness, the constellation and cooperation of the local actors as an indicator for the dynamism and renewal of the regional production system. The local and regional actors were classified as innovators, followers, transformers, or beneficiaries. The internal core of the initiative was called a clique. For the sample of interviewees, see Tables A2 and A3 (Appendix A). The selection of the interviewees was based on the snowball principle. In the present case, this resulted in a somewhat underrepresentation of ordinary beneficiaries, i.e. the nonactive residents (and thus, also possible critical voices). Furthermore, the empiric analysis based on the long-term monitoring of Swiss regional development (especially $[6,38,39]$. It was the aim, firstly, to identify and describe SI initiatives that stand for a dynamic development of mountain areas and enable their connectivity to an urbanised Switzerland in order to avoid large-scale regional disparities. As elsewhere, urbanisation in Switzerland proceeds in the context of a large-scale division of labour between producing and consumption-oriented regions and in the frame of changed concepts of regional policy. Therefore, due to the research objective as well as our own understanding of SI, the research focus for Switzerland was not on the outcomes, but on the long-term evolution: the impact on territorial disparities, the impact on the relationship between metropolitan areas and its hinterlands, and the impact on rural-urban linkages. Secondly, it should be possible to discuss the transferability of the results to other mountain regions, at least in the countries of the global North. 


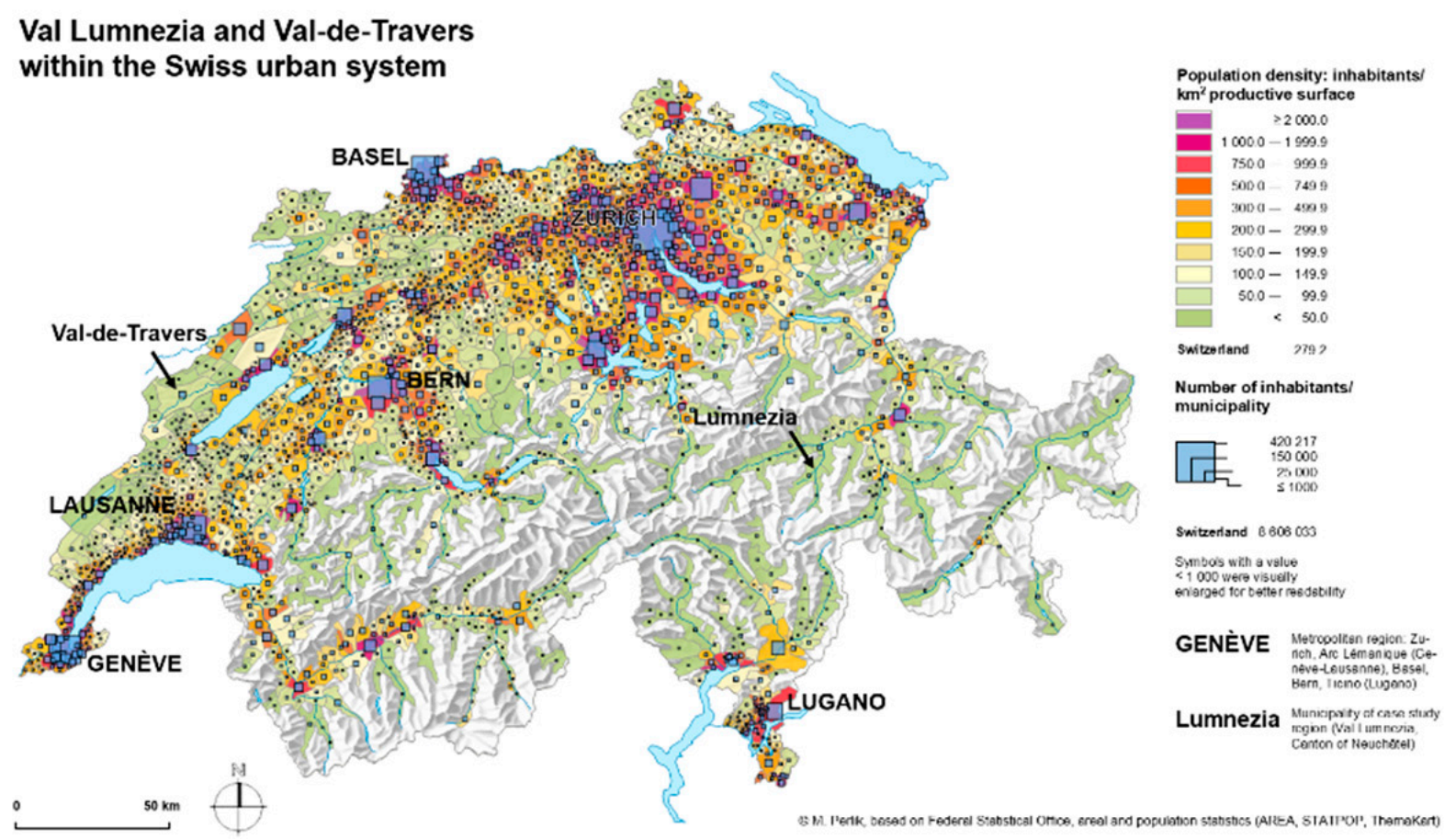

Figure 1. Val Lumnezia and Val-de-Travers within the Swiss urban system.

Table 1. Demographic development in Val Lumnezia and Val de Travers compared to the growth of the metropolis of Zurich (Swiss Federal Statistical Office, ESPOP, https:/ / www.pxweb.bfs.admin.ch/pxweb/de/?rxid=71148ed7-3658-4dd9-a021-6 96e8c37e362 (accessed on 10 February 2021); Cantonal Population Surveys, Statistical Office of the Canton of Zurich, https: //statistik.zh.ch/internet/justiz_inneres/statistik/de/daten/daten_bevoelkerung_soziales/bevoelkerung.html (accessed on 10 February 2021).

\begin{tabular}{|c|c|c|c|c|c|c|c|c|}
\hline Peripheral Valleys & 1970 & 1980 & 1990 & 2000 & 2010 & 2017 & 2018 & 1990-2018 \\
\hline $\begin{array}{c}\text { Lumnezia } \\
\text { (11 villages merged) }\end{array}$ & 2527 & 2262 & 2254 & 2309 & 2216 & 2047 & 2026 & $-10.1 \%$ \\
\hline $\begin{array}{c}\text { Val-de-Travers } \\
\text { (9 communities merged) }\end{array}$ & 12,549 & 10,169 & 10,749 & 10,910 & 10,832 & 10,745 & 10,668 & $-0.8 \%$ \\
\hline Metropolitan & 1970 & 1980 & 1990 & 2000 & 2010 & 2017 & 2018 & 1990-2018 \\
\hline City of Zurich & 422,640 & 361,441 & 347,634 & 334,298 & 372,047 & 407,447 & 413,912 & $+19.1 \%$ \\
\hline
\end{tabular}

\section{Territorial Relations in Switzerland}

Since the founding of the federal state in 1848 , Swiss political and social institutions have taken the social question seriously, mainly in its territorial dimension. This is expressed in a balanced system of formal and informal institutions, participation rights, and policies to avoid profound regional disparities [39]. Nevertheless, after the Second World War, in the booming Fordist period, Switzerland's rural areas lagged considerably behind the prosperous Plateau Area (Mittelland), not benefitting from state subsidies until the 1970s/1980s, when regional policies in favour of equality - the LIM law and similar measures-were introduced [40]. These instruments came too late to deploy their full potential as the regime change towards post-Fordism had already set in [6], accompanied by the renaissance of the city, urban lifestyles, and research in favour of new urban models [41]. The following Neue Regionalpolitik (New Regional Policy, NRP) [42-44] focused on increased regional competitiveness, innovative potential, and entrepreneurship. We may see this as innovative for its time in that it replaced the previous Fordist regime (which often meant the construction of heavy infrastructure to achieve equal accessibility) with a call for a specialised offer-oriented presence of the regions in external markets. The 
proponents of this shift demanded to abandon the (in the Swiss context) most peripheral areas, named potenzialarm (potential-poor). Arguments for abandoning varied alternately according to particular interests, such as the environmental qualities of wilderness areas, the high infrastructure costs for taxpayers, or the creative potential of Alpine fallows.

In this context, the paradigm shift was a recourse to the innovative power of the individual entrepreneur of the Schumpeterian type, with the spatial model being the Italian industrial district. An apt critique of this model was given by Costis Hadjmichalis [45]. In terms of economic value creation, the paradigm shift to post-Fordism was innovative for its invention of a new, questionable consumerism; in terms of its governance mode (regulation) - the distribution of resources-it was not innovative at all: it was actually regressive as societal polarization increased again. However, the Fordist model of equal development had been discredited before, economically (low value adding), ecologically (growth ideology), and socioculturally (imperial policies towards the Global South).

The case study regions had either not benefited from the post-war upswing or were experiencing the first economic crisis. Val Lumnezia missed the tourism boom of the Alps. The Canton of Neuchâtel experienced the first economic decline after the war with the watch crisis of the 1970s and has remained fragile since then. In this situation, it was innovative that in Val Lumnezia as well as in the canton of Neuchâtel, a new generation of actors used their skills and networks to create a new dynamic in their home regions. In both cases, they drew on external knowledge that was, however, restricted to be within their reach, i.e., within their social milieus. In the case of Val Lumnezia, it was the national lobby organisation for mountain areas Schweizerische Arbeitsgemeinschaft Berggebiete, SAB (the Swiss Working Group for Mountain Regions); in the case of the Canton of Neuchâtel, it was the social capital giving easy access to the federal administration. The social innovation consisted of responding to a socially and economically changing situation with new development strategies by a new constellation of social actors. This already can be named as at least an adaptive SI. The SI-initiatives show that peripheral regions defend their position, claim equal or similar livelihoods and try to develop a new dynamism.

The Val Lumnezia (Figure 2) is one of the few areas of Switzerland that are unreservedly classified as peripheral [41,46-48], located in the Romansh-speaking part of Switzerland and one of the few areas still dominated by small-scale agriculture. The main village of Vella is located at $1244 \mathrm{~m}$ altitude. The last permanently inhabited village, Vrin, is at $1448 \mathrm{~m}$. A young generation of artisans and small traders founded the initiative Pro Val Lumnezia. After the apprenticeship outside they had come back, looking to reestablish themselves and to generate work and jobs for their trade by trying to benefit from tourism, which did not have any tradition in Val Lumnezia. They dreamt to benefit from mass tourism like in other parts of the Alps. This effort came too late-a stroke of luck from today's perspective. The initiators sought professional advice outside the valley, but within their social and professional milieu. At that time, the SAB had also made progress compared to the heyday of growth-oriented production. They recommended a small-scaled niche tourism [49]. For the first time a regular cooperation was agreed upon with the Grisons environmental movement, which created a constellation of actors who had previously been hostile to each other and who are-in the Alpine regions-still today firm political adversaries. Another example of external learning is the cooperation on construction issues with the Federal Institute of Technology Zurich (ETHZ) to fulfil the needs of today by at the same time preserving the old qualities of the densely built villages. Again, this was external knowledge that was accessible to them, as the responsible for this approach of architecture had grown up in the valley. It is interesting to notice that, during the innovation process, the change in power structures did not manifest itself in a change in the dominating political party; it was people within the party who changed their attitudes. Another interesting aspect is that the initiative started with an entrepreneurial interest that turned into a civil society activity and ended as a public institutional profile-in other words, an outcome-oriented initiative evolved into an impact-oriented project. Over the course of 20 years, various projects have emerged (building hiking trails, supporting alpine 
farming, the construction of a local butchery), which have strengthened the character of the valley as a rural tourist region, initiated cooperation between the smallest municipalities, and improved its reputation at the cantonal and national level. The peripheral and inferior position has not changed in general, nor has the number of inhabitants grown. However, it did not decline considerably; and-very important-it contributed to a holistic territorial policy (as opposed to the formulation of low-potential areas, cf. also [50,51]. Pro Val Lumnezia officially ended with the fusion of the small villages into one municipality in 2013. It was transformed into the association Ir novas vias (New ways for a sustainable future), now also focussing on the second-home owners in the whole Surselva region. The trajectory of the initiative is shown in Figure 3.

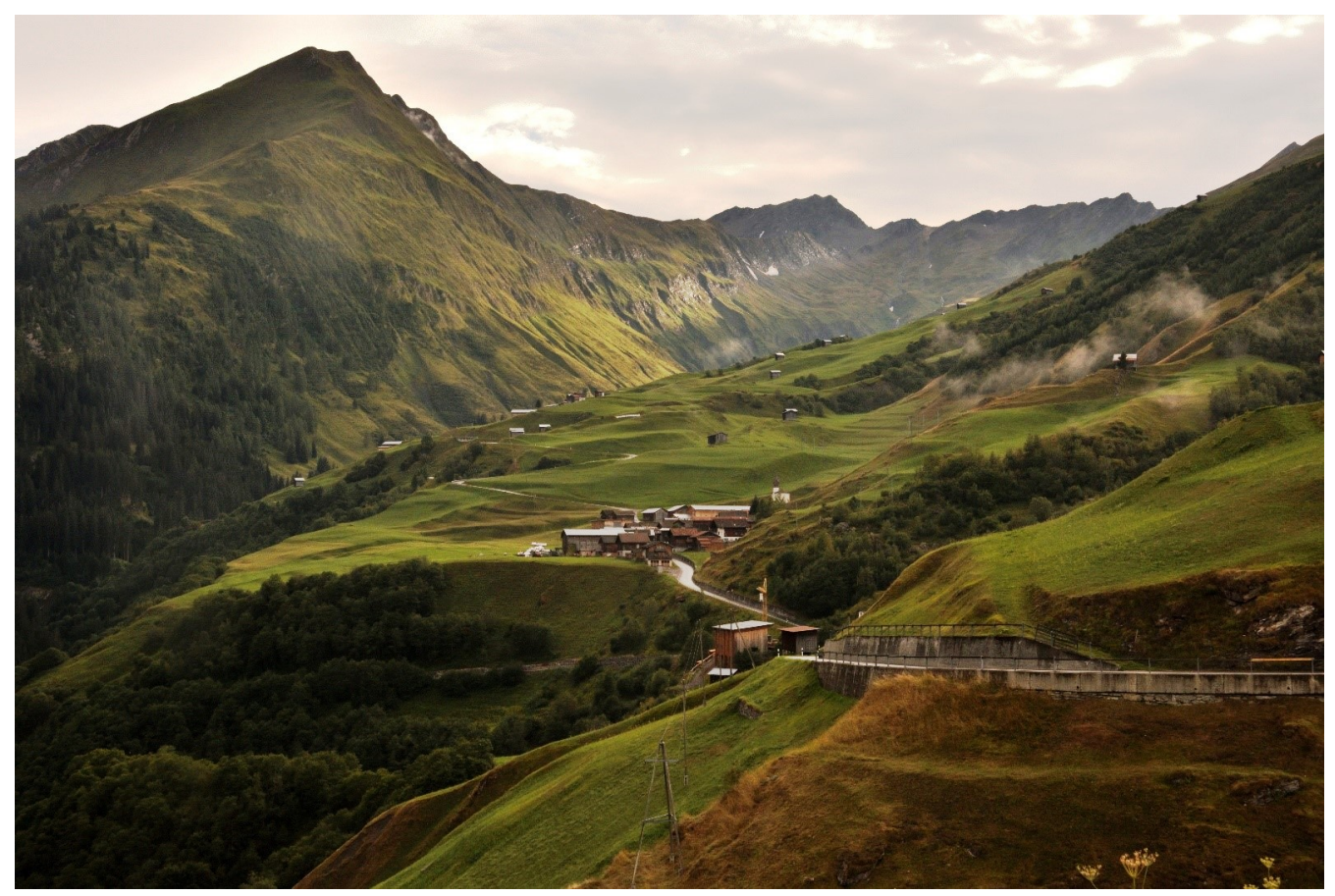

Figure 2. The hamlet of Vrin Cons at $1460 \mathrm{~m}$ altitude (N $\left.46^{\circ} 39.212^{\prime}, \mathrm{E} 9^{\circ} 5.883\right)$ is one of the last permanently settled hamlets at the end of Val Lumnezia. The territory is still mainly used for pasture farming. (C) Photo: M. Perlik.

The Canton of Neuchâtel is located at the southern fringe of the Jura Mountains, a low mountain range of up to $1720 \mathrm{~m}$ altitude with the two medium-sized towns of La-Chaux-de Fonds at $1000 \mathrm{~m}$ altitude and the cantonal capital of Neuchâtel at the foot of the mountains at the lake of the same name. The valleys between the cities are relatively sparsely populated. The region has a long-standing industrial profile, with the watchmaking and precision mechanics industry as the leading sector, which has been struggling with structural change since the 1970s. The Réseau Urbain Neuchâtelois was launched in 2006 by a new generation of chief officers in the cantonal administration, with the aim of holding together the two parts of the canton that were drifting apart. While the lakeside municipalities benefit from strong peri-urban growth, the lateral valleys suffer stagnation and outmigration and the city of La-Chaux-de-Fonds has lost significance. A joint infrastructure project, a fast urban railway line linking the whole canton, was planned but not realised. It was an early project in favour of what is now called "rural-urban linkages". 


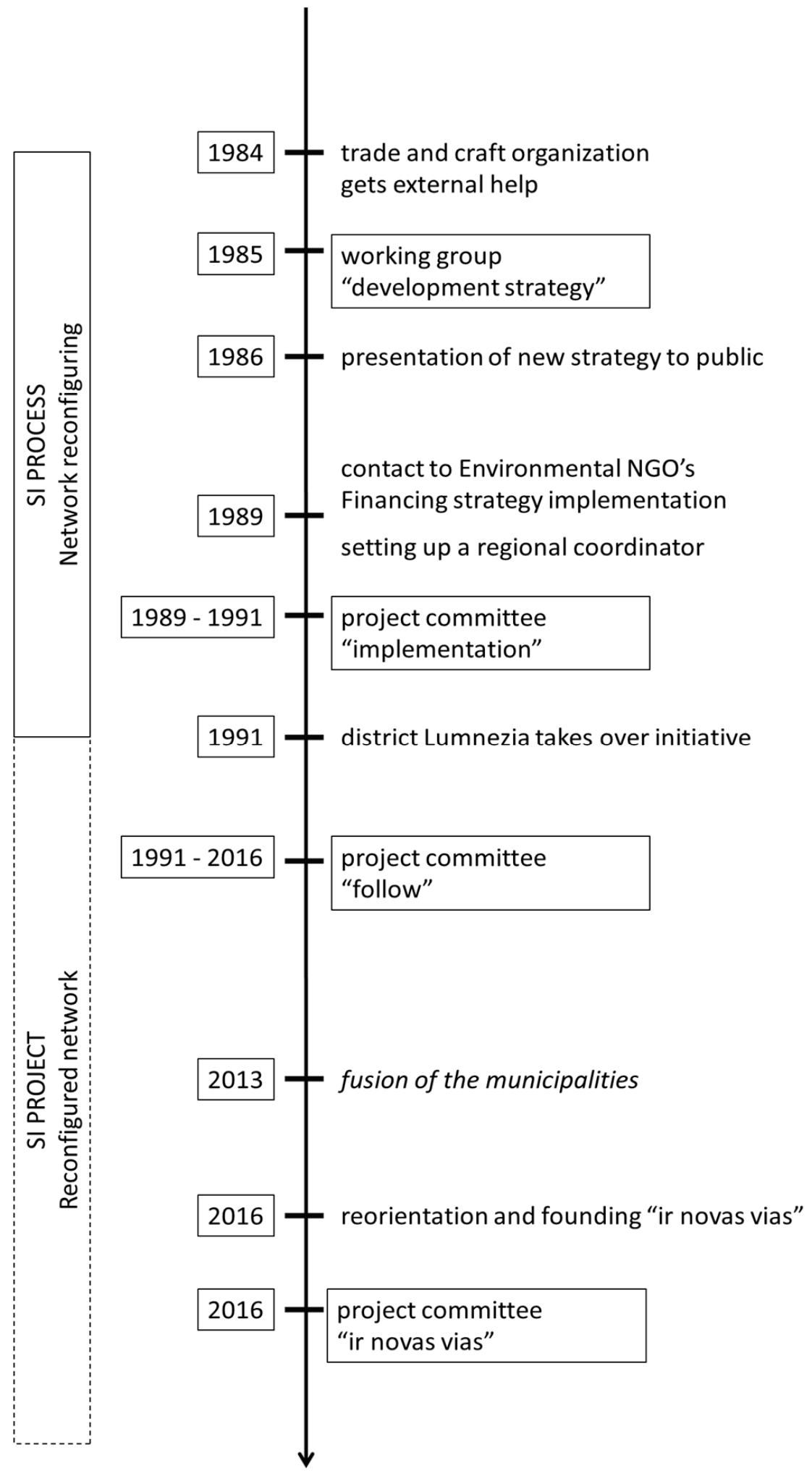

Figure 3. Chronology of Social Innovation in Val Lumnezia (Switzerland). Own elaboration based on the focus group and interviews [52]. 


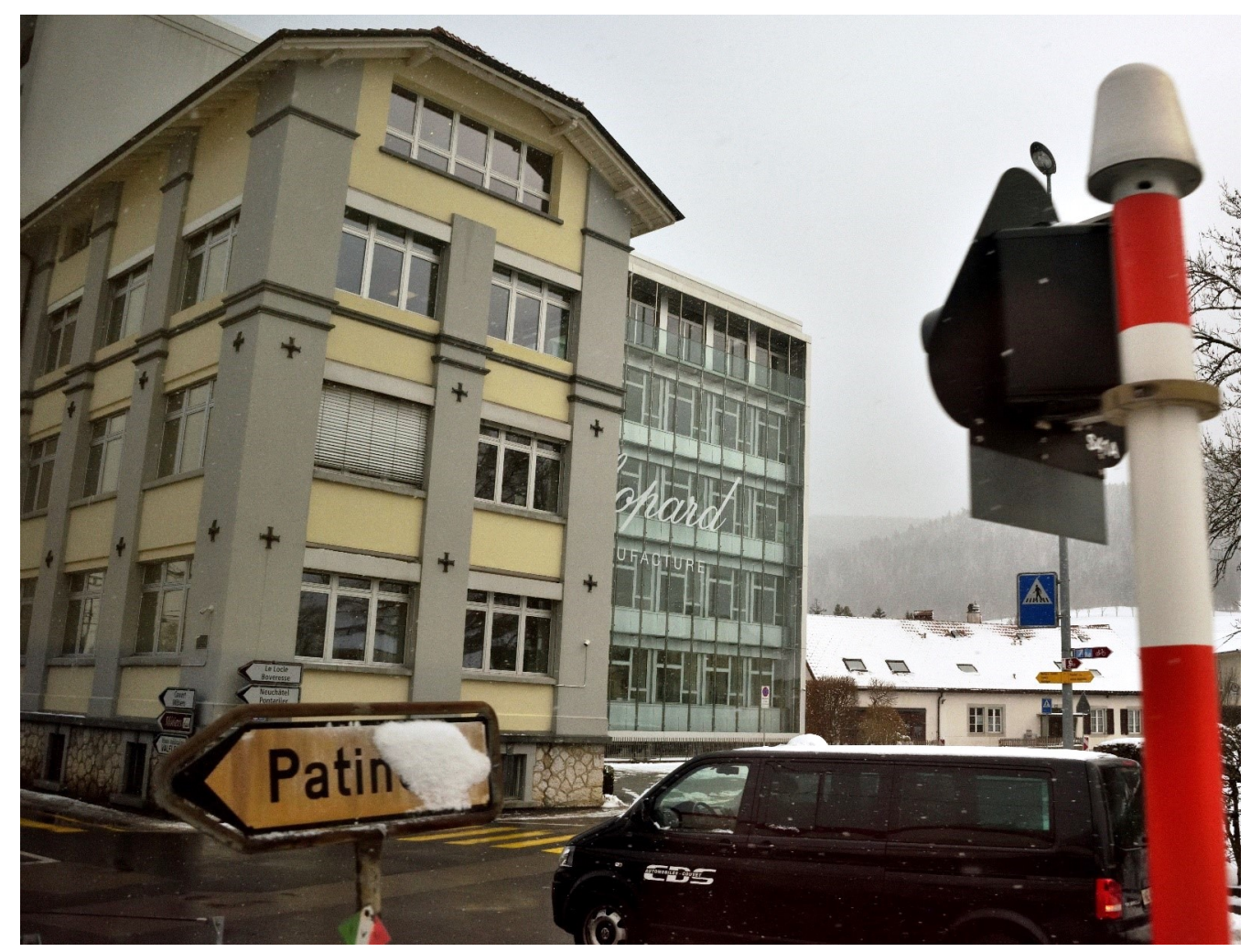

Figure 4. The largest municipality of Val-de-Travers, with more than 3500 inhabitants, is located in the upper part of the valley $\left(\mathrm{N} 46^{\circ} 54.312^{\prime} \mathrm{E} 6^{\circ} 35.019^{\prime}\right)$ at $736 \mathrm{~m}$ altitude. It is the main site of a high-end watchmaking manufacturer. This is typical of the canton of Neuchâtel in that it hosts not only manufacturing but also research and development, while the business services industries are located in densely metropolitan lowland areas. (C) Photo: M. Perlik.

The initiative also served to maintain and further develop the industrial profile and to promote the territory becoming more diversified but on an equal footing by defining it as an urban project-an agglomeration covering the whole canton. For this purpose, a new institution in the legal form of an association was created. Furthermore, in Val-de-Travers (Figure 4), one of the lateral valleys, cooperation between the export-oriented economy and the valley communities was institutionalised with the creation of the Association Réseau des Fleurons (Network of Blossoms). The improved and formalised cooperation between the municipalities eventually led to a merger of the valley's municipalities. The initiative attracted the interest of the federal administration, which promoted this project with a generous budget as a pilot project within the framework of its newly developed NRP. Not all the planned measures were successful and the canton is still disadvantaged by structural fragility. However, the initiative has helped the canton to make its concerns heard at a national level, and it has benefitted from its performant manufacturing and a small newly developed tourism. The trajectory of the initiative is shown in Figure 5. 


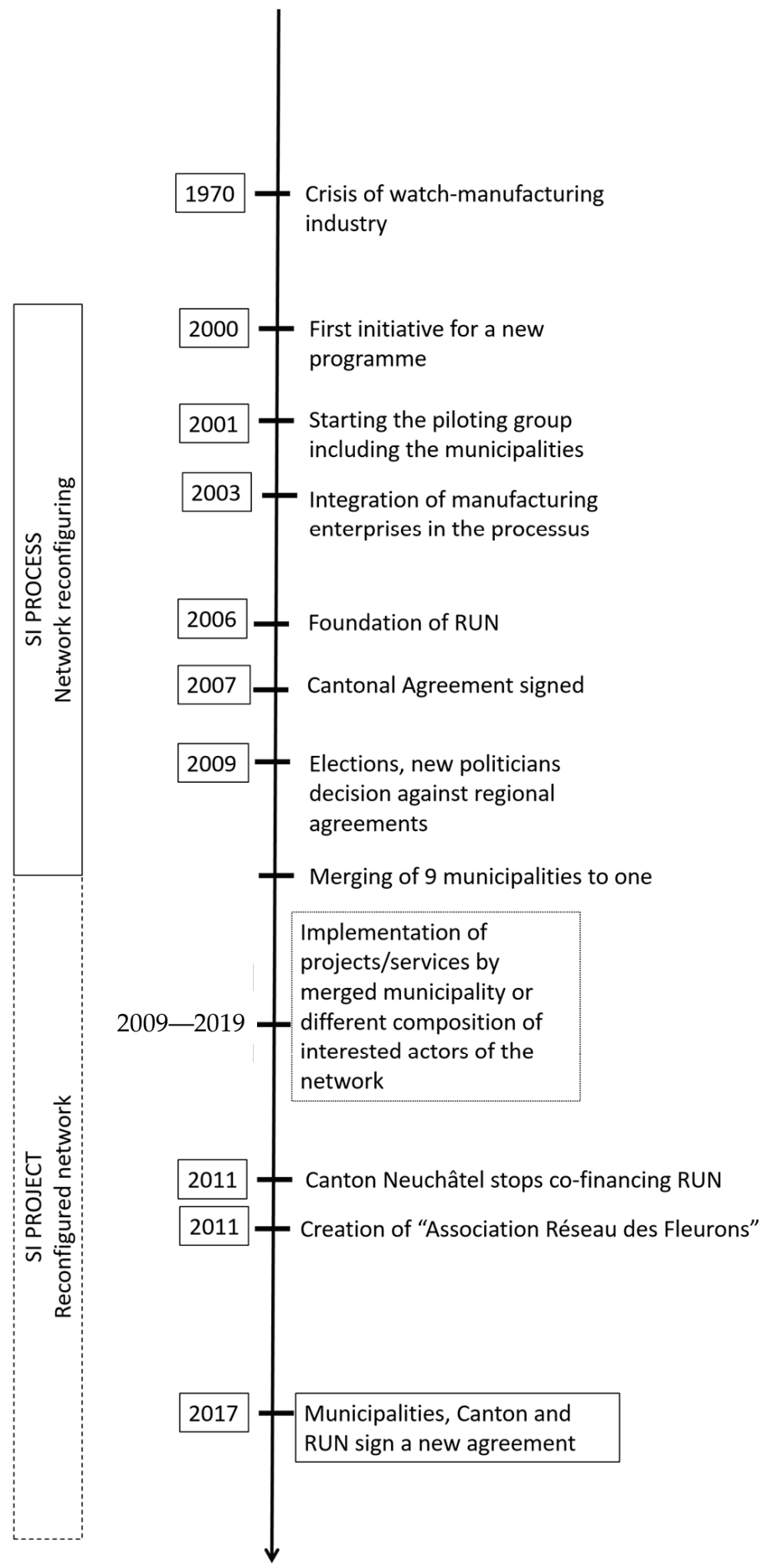

Figure 5. Chronology of the Social Innovation in Val de Travers (Switzerland). Own elaboration based on the Focus Group and interviews [53].

\section{Results of the Semi-Structured Interviews: Positive Impacts of the SI Initiatives}

Due to the selection criteria for the SIMRA project (presumably successful initiatives), positive answers could be expected; it was above all a question of how strongly positive the answers would be and which points would be emphasised. We also must note that the interviewed persons were mainly actively involved as SI protagonists (i.e., only a small number of beneficiaries). From the interviews, only semi-structured parts were taken for this paper, which means that we have mainly qualitative results (Table 2). 
Table 2. Elements of the four domains with strongly positive impacts of the SI initiative's activities in Val Lumnezia and in the Canton of Neuchâtel/Val de Travers. Data from Focus Group (tool 2) and qualitative interviews (tool 9). Source: [52,53], modified.

\begin{tabular}{|c|c|c|}
\hline \multirow{2}{*}{ Domain } & \multicolumn{2}{|c|}{ Elements } \\
\hline & Val Lumnezia & Canton of Neuchâtel/Val de Travers \\
\hline Economic & $\begin{array}{c}\text { Infrastructural investments } \\
\text { Creation of new economic and social activities } \\
\text { "... I believe that prosperity has increased, I do believe that } \\
\text { the farmers have increased their prosperity ... " (LUM004) } \\
\text { "... a few nice projects have been created ... " (LUM004) } \\
\text { "... some melioration took place and the hiking trails that } \\
\text { nobody thought of, we came and said, we need the hiking } \\
\text { trails, we have to create new ones... " (LUM001) }\end{array}$ & $\begin{array}{l}\text { Creation of new economic and social activities } \\
\text { Consolidation of existing activities' network }\end{array}$ \\
\hline Social & $\begin{array}{l}\text { Community solidarity } \\
\text { "... if you want to get ahead, you have to work together } \\
\ldots \text {.. (LUM011) }\end{array}$ & $\begin{array}{c}\text { Community solidarity } \\
\text { "Acceptance of the principle of union of the population, of the } \\
\text { gathering of the population ..." (FLE004) } \\
\text { Trust in the community } \\
\text { Access to quality education for kids and youth } \\
\text { Options for life-long learning } \\
\text { Welfare and social expenditure }\end{array}$ \\
\hline Institutional/governance & $\begin{array}{l}\text { Empowerment and representativeness of } \\
\text { stakeholders in the decision-making process }\end{array}$ & $\begin{array}{l}\text { Relationships between public organisations, businesses, } \\
\text { and civic associations } \\
\text { "However, for the first time, the industry was taken into } \\
\text { consideration. For the first time, we asked ourselves: What can } \\
\text { industry bring to this vision of this project? This was an } \\
\text { important step." (FLE006, Tool 2) } \\
\text { Capacity of public administrations to manage collaboration } \\
\text { and dialogue between public actors and between the } \\
\text { private sector and civil society } \\
\text { Sharing of data, knowledge, and experience } \\
\text { Transparency and accountability of both private and public } \\
\text { organisations } \\
\text { "What are the changes? It is transparency, it is creativity and it } \\
\text { is a willingness to share" (FLE002) }\end{array}$ \\
\hline Ecological & $\begin{array}{c}\text { Not explicitly noted but always implicitly present as } \\
\text { a topic for the future: environmentally friendly } \\
\text { development in the valley }\end{array}$ & Not the focus of the initiative \\
\hline
\end{tabular}

For our question - the evaluation of long-term impacts and territorial trajectories in two single cases - the qualitative approach was more promising as it necessarily needs context knowledge which cannot be provided by standardized questionnaires. In contrary, the quantitative tools are useful to measure and compare (short-term) outcomes or to compare a larger number of cases (the quantifiable results are published elsewhere, e.g., [1,54,55], and in the detailed Lumnezia and Neuchâtel/Val de Travers reports [52,53]). Our question was not how and which services in the mountain area are specifically stabilised or expanded; also, it was of less importance whether their position in intranational competition of rural areas could be improved. This is because, firstly, Swiss mountain areas are not isolated enough to have to build completely new institutions beyond state public institutions for basic services. Indeed, the national state has reduced activities in the territory, but not as much as in other countries. Secondly, it cannot be expected that civil society initiatives alone could overturn hierarchical relationships at the national level. What the studies can show, however, is how a sparsely populated region (Figure 1) can achieve a new dynamic through a partial renewal or even a complete replacement of the present decision-makers and thus successfully overcome adaptation problems. Such changes are necessary when the loyalty of the old stakeholders no longer exists or when their power has diminished to continue social commitment and economic renewal capacity (expressed in a lack of attractiveness). Or, to an even greater extent, when a restructuring sector can no longer be maintained at its historic location and has to adapt to changed global regimes. In these cases, the already reduced number of local/regional stakeholders must move closer together. This is shifting the local and regional power structure. In an ideal case, the 
demographic and institutional structure can be stabilised for the next decade(s) until the next generational or technological change.

\section{Results of the SNA: Strengthened Ties among Actors of the SI Initiatives}

\subsection{Val Lumnezia}

A complete exchange of the old decision-makers-smallholder farmers and small village officers at volunteer basis-took place, initiated by a younger generation who had other ambitions and skills. They shifted the structure of the valley from a highly agrarian and overaged subregion with individually acting microcommunities to a more agritourist profile. The urban skilled artisans and small entrepreneurs had a larger, supraregional professional network and were more open to cooperation with other social milieus. The SNA shows the convergence of this new network over time through the expansion and densification of this milieu in three pictures (Figure 6a-c).

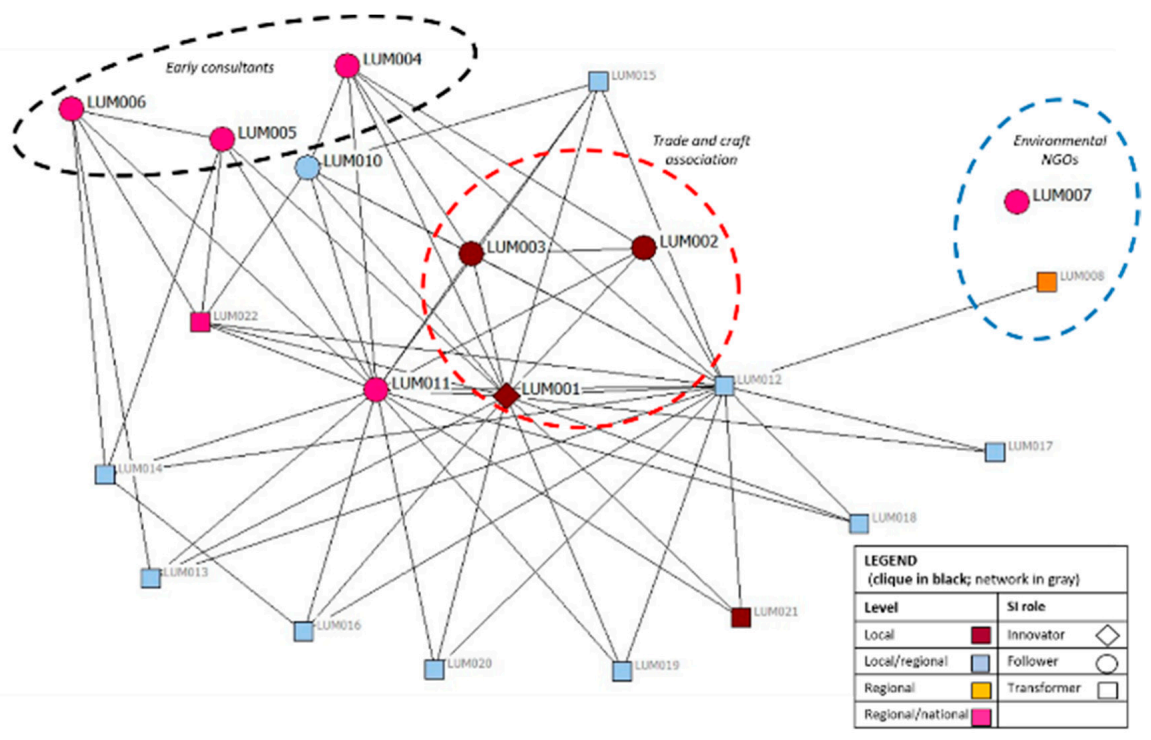

(a) Pre-trigger social network before 1985. The majority of the network members already had contacts between themselves before. The cluster of local actors related to the trade and craft association, and especially the innovator, were already acting as a bridge to the remaining future members of the association.

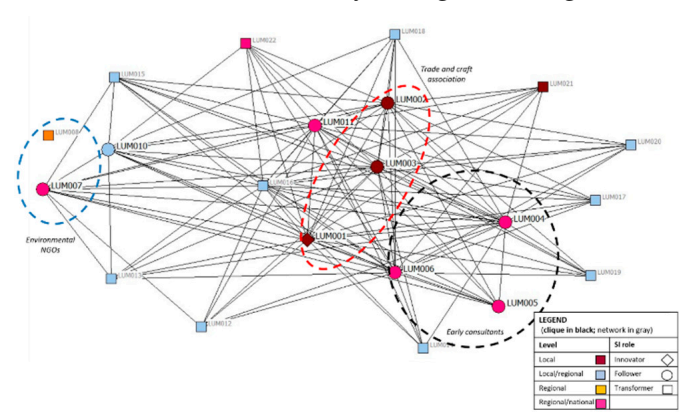

(b) The process of reconfiguration from 1985 until 1991 (drafting a new development strategy for the valley). The graphic shows a substantial increase in connections between all actors. The network density increased as well. The trade and craft association has consolidated as gatekeeper between all actors.

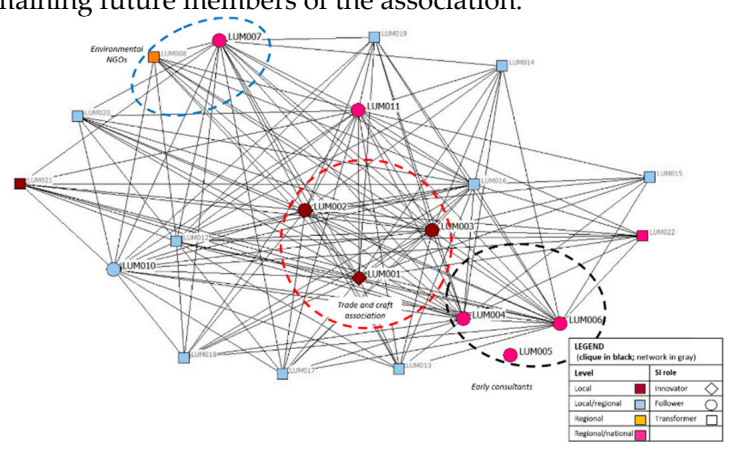

(c) The implementation phase of Pro Val Lumnezia from 1991 onwards. The network has become denser. The network of actors has consolidated. The role of the early consultants who helped during the reconfiguring phase diminished in strength.

Figure 6. The evolution of the social network of the SI initiative Pro Val Lumnezia, modelled and visualized by a social network analysis. The symbols refer to the different roles of the actors within the SI (innovator, follower, transformer, and mainstreamer as shown in Table A1 in the Appendix A). The internal circle of the SI initiative (innovator and followers) is named the clique. (C) V. Marini Govigli. 


\subsection{Canton of Neuchâtel}

It was actors from the existing cohabiting milieus (entrepreneurs from the manufacturing industry and cantonal officers), but from a new generation, who founded a new dynamic that involved more formalised and transparent cooperation between the public and the private milieu. In one of the Neuchâtel valleys (Val-de-Travers) this expressed in the creation of a network of export-oriented larger enterprises and its formalised cooperation with the public administration as well as (on the level of the whole canton) the organisation of vocational training focussed on the needs of the regional production system in the manufacturing sector. In the SNA (Figure 7a-c), this change was hardly visible: there was no network growth and densification. We can explain the lack of densification by the fact that the relevant actors already had strong ties before the SI reconfiguration process started; in addition, the lacking database adds bias to this picture. One important supplementary reason was that the development of the initiative was interrupted temporarily by an unexpected election result. Subsequently, the key person left his position and moved away from the region. However, the interviewees noted that the process was continuing. They also considered the municipality merger, initiated during the initiative, as a success.

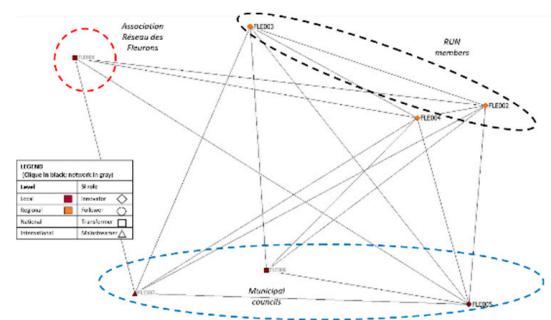

(a) Pre-trigger social network (before 2001). The figure shows that, before the creation of the initiative, the majority of the network members already had contacts between themselves. In particular, note the cluster of local actors related to the RUN, the innovators, and the representatives of local councils. The Neuchâtel case is an example of long-term cohabitation and collaboration between two different milieus.

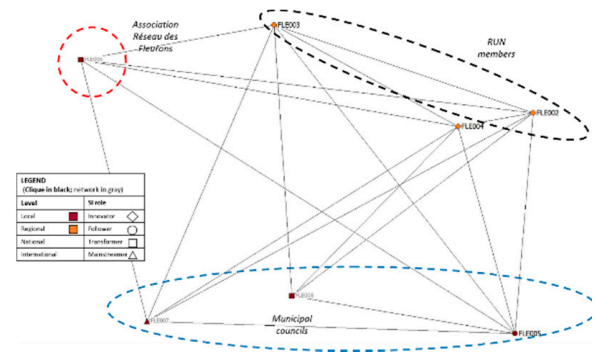

(b) Network reconfiguring process from 2001 to 2007. In contrary to the general perception, only one new relationship was established (between FLE003 and FLE006).

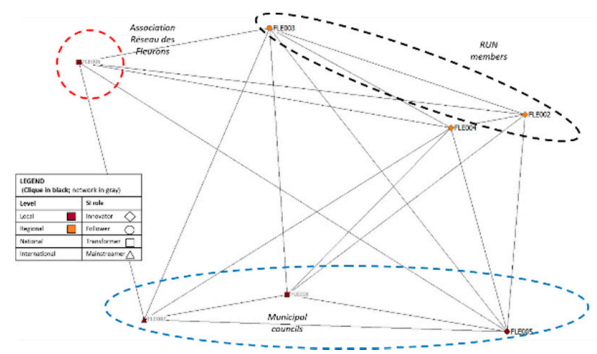

(c) Implementation/reconfigured network phase from 2007 onwards. As happened for the previous period, no substantial new relationships were established, except a new tie between FLE007 and FLE008.

Figure 7. The evolution of the network in the canton of Neuchâtel. The symbols refer to the different roles of the actors within the SI (innovator, follower, transformer, and mainstreamer as shown in Table A2 in the Appendix A). The internal circle of the SI initiative (innovator and followers) is named the clique. () V. Marini Govigli. 


\section{Discussion of SI from the Perspective of Spatial Sustainable Development}

\subsection{What Is a Social Innovation?}

The inflationary use of the term innovation as a seal of approval or brand obscures what this term refers to and in what context it was developed. Concerning territorial development, which is a holistic societal goal, the qualification of being innovative cannot be measured by the outcomes of a higher regional performance. The post-Fordist paradigm shift since the 1980s has demanded just this as a crucial goal of development strategies. A change in strategy in this direction is, on the one hand, not a social, but an economic innovation (replacing political decisions with market laws). On the other hand, it is not new; economic actors have always tried to align political institutions and public services according to the interests of regional value adding, as it ameliorates the conditions for their entrepreneurial milieu. In this sense, regional performance certainly does play a role, as without the positive development of a region, stakeholders (residents as well as entrepreneurs) will quit the territory while good skilled immigrants will avoid it. For the qualification of "SI," however, it is crucial that it includes a change in social practices.

\subsection{Adaptive or Transformative?}

This is a question of scale-a problem of the temporal and spatial perspective $[56,57]$. We estimate the innovative leaps in both cases as "adaptive" because it occurred in a period of post-Fordist change, which found its expression at the governance level in Switzerland in the NRP. It was the core of the regime change to make peripheral regions more accountable for maintaining their own competitiveness in order to reduce area-wide subsidies. In the case of Lumnezia, this message spread through the external consultants; in the case of Neuchâtel, it spread through cooperation (and funding) with and by the federal administration. In neither case did the initiatives come from system-critical protest actions, the creation of a new form of cooperatives or similar grassroots movements, or from ideas and approaches that would have challenged the traditional logic of growth or the current spatiality regime, which, in this sense, would have had a far-reaching transformative effect.

In both cases, the interaction between actors from the three types of institutions (public, private, and civil society) played a decisive role. On the one hand, this cooperation was based on long-term, Switzerland-specific modes of regulation (the specific trajectory of a consensus-oriented governing and administration system). On the other hand, this cooperation was renewed. This renewal also followed traditional governing practices as it is usual for new groups of social actors to become accepted when they have proven a certain degree of seriousness and patience. This is valid for the integration of the environmental movement as well as for the creation of a public-private partnership and the integration of new industries. Therefore, the Swiss context is important. In the Fordist period, Switzerland had generated the funds to finance national equalisation policies and infrastructure construction in the interest of territorial cohesion [6]. With the renaissance of cities, this practice of rural development was critically questioned [41]. Ultimately, the change in policies was not as radical as was claimed. However, we can say that, in both cases, the SI initiatives were an expression of the upheaval and adaptation in the mountain area. They have initiated the transition from traditional and regionally isolated production systems (as a prerequisite of Global Change) without sacrificing the essentials of the region's specific trajectory. Through this, they could shed the stigma of low-potential areas.

\subsection{Are the Swiss Cases Transferable?}

Changes in social practices occur in order to cope with conditions perceived as no longer tolerable. This happens in a crisis situation when current conditions (exogenous, endogenous, or both) are changing. In the Alps and the Jura, the need for SI arose at the end of the 1980s when regions became exposed to new forms of international competition and were included in global value chains (tourism, food, real estate, raw materials, and ecological branding). Simultaneously, agglomeration advantages for global hubs grew. In response, peripheral regions were told by economists and regional policy makers to develop 
strategies of uniqueness, i.e., new products, sectoral specialisation, and affirmations of regional identity. At the time when Pro Val Lumnezia and Réseau Urbain Neuchâtelois started, the global transformation towards deregulation became visible. This regime change was certainly not a social innovation, as its outcomes and its impact created a social relationship towards more inequality as well as social and territorial cleavages (empirically proved for several countries as a resurgence in inequality after an eight-decade decrease $[58,59])$ ). As it was relatively new, it was a renewal of Fordist capitalism, and in this sense, it was certainly an economic innovation. The regional responses in our two case studies can definitely be named social innovations of the adaptive type, as they tried to maintain their position in the regional hierarchy, their socioeconomic trajectory, and their collective wellbeing under the growing pressure and uncertainties of global change (and its apologists in Swiss economy and politics; one example was the strategic decision to favour Switzerland as a finance hub, sacrificing the other important sector-manufacturing - by pursueing the currency policy of a strong Swiss Franc [60]).

It is this aspect that makes the two Swiss SI initiatives, despite all their differences in terms of national wealth and federal governance structures, transferable to other mountain regions in Europe and the global North. It is mainstream to advise peripheral regions to develop unique selling points and to use this strategy to gain market shares in the sectors in which they are specialists. In some respects, the two initiatives were also oriented towards this goal. However, they had an advantage in that they did not directly copy other concepts, which made them innovative. It is a dilemma for all peripheral regions: On the one hand, it is a risky strategy; if it fails, the investment is lost. Furthermore, it is a traditional growth strategy of outcompeting similar peripheral regions in the struggle for resources. Neither is very sustainable. On the other hand, they do not have many alternatives, at least in the logic of adaptive SI. A way out of this dilemma may be a changed, more egalitarian relationship between lowlands and mountains, constituting a changed spatiality in terms of governance and deciding power. The "lessons learnt" of the two case studies in the following subsection may be useful for such an orientation and may be transferable for other regions in the global North. For emerging countries-especially after the financial and pandemic crisis - this case is transferable only in its general mechanisms stressing on the interplay of functioning institutions of public, private, and NGO milieus that do not block each other (which of course, again, are dependent on societal wealth).

\subsection{Impacts of SI on the Changing Spatiality between Lowlands and Mountains, and Potential Transformations}

(a) Shifting power relationships within the local communities. Social innovations affect the institutional arrangements in a given territory. The emergence of an active civil society is not a prerequisite but an indicator. Traditional economies and public bureaucracies have come under pressure or lost significance due to a lack of loyalty from members (e.g., by outmigration) or a lack of support from development agencies. The emergence of a civil society expresses the vitality of a region through an active citizenship that wants to have influence or fill a vacuum. Often these active people belong to a younger generation or a new sociocultural milieu. Therefore, they do not yet belong to a predefined group of actors, but this may change in the process of establishment, i.e., becoming a more private or a more public body. In the Swiss cases, this meant the renegotiation of relationships between the three types of actors. In Lumnezia, it was triggered by a new generation of artisans who wanted to work in their own profession and reduce the dominance of farmers in favour of construction and tourism. During this process, they opened up institutionalised discussions with the Grisons environmental organisations. Although the initiative came from entrepreneurs, it ultimately strengthened the position of public institutions. In the Canton of Neuchâtel, it was a new generation of chief officers who wanted to give a new dynamic to this canton by maintaining its industrial profile. As in Lumnezia, a municipality merger took place. Additionally, as in Lumnezia, it was (perhaps by coincidence) not the initiating public milieu that was finally strengthened but the other, private one (even if not so clearly), in the form of institutionalised cooperation with the municipality and 
the establishment of an association structure for regional development. In summary: Within the framework of successful Sis, a redefinition of the relevant regional forces and a reorientation of the trajectory takes place. It may cause trouble at the beginning but finally it strengthens stability and cohesion.

(b) The role of strong individuals. Due to the sparse population, mountainous areas are vulnerable to changes in political power, the collapse of key industries, and the loss of key persons. Both case studies show that the initiatives are strongly tied to the motivational power of individuals; the removal of one of them can interrupt or even end the innovation process. Every SI has its own half-life and its expiry date. This is the case when a new social practice becomes established and mainstream (locked-in) or when the initiative has not been able to establish itself and its potential becomes exhausted. In addition, the departure of the first generation of initiators proves to be a particularly severe break. This was the case in Lumnezia. In Neuchâtel, it was the change in the cantonal government that cut off the support to the initiators and led to the key person quitting; this threw the initiative off course. This is worth considering, as a policy body normally is expected to be more stable. It follows that we cannot propose a general recipe: civil society, entrepreneurship, and the public sector by themselves cannot ensure innovation, but the interaction of all three can; this depends on the integrity of their leading persons. The Swiss governance system, with its participatory, direct-democratic understanding of the state, tripartite cooperation between state institutions and active involvement of civil society, offers in general good prerequisites, but one has to keep in mind that even under such favourable conditions every new movement has to fight—sometimes very long — to prove its seriousness and become an accepted stakeholder (e.g., women in Switzerland achieved general voting rights only in 1971).

(c) Creating larger networks. In Lumnezia, the decision to ask for external consultancy opened the way for new knowledge and urban milieus. In Neuchâtel, the new chief officer motivated a new cantonal strategy with a convincing concept. In both cases, this access to newly becoming state-of-the-art practices on national level generated a new dynamic in the peripheral regions. In both cases, this strategy also won acceptance on a national level: the peripheries proved to be innovative. At the national level, the NRP was intending a stronger market orientation and the abandoning of the traditional equalizing development. Benefitting from this new political climate, the Lumnezia initiative received new ideas; the initiative in Neuchâtel received considerable funding. Paradoxically, from the point of view of federal administration, these initiatives proved that even supposedly "low-potential" and old industrial areas can be innovative. What seems to be missing in both cases is grassroots movements: experiments with the social and solidary economy or expressions of youth activities, as known from urban areas, but also the creation of new institutions, which may be formal or informal.

(d) Bridging different socioeconomic cultures within the valley. Social innovations can emerge in the public, private, or civil society sector. Depending on the milieu of its protagonists, civil society is more familiar either with entrepreneurial or state values. Initiatives are professionalising in the direction of one or the other milieu. Civil society, therefore, means, above all, a new generation that seeks and-if successful-finds its place in society. With this generational change, the milieu-typical characteristics are also changing. On the one hand, alignment is possible. For example, at the national level in Switzerland, civil society environmental organisations have aligned themselves with private sector practices (especially in marketing). On the other hand, new institutional and organisational forms are also created, e.g., in the form of producer-consumer cooperatives or contract farming. In Lumnezia, the impact of the SI initiative resulted in a more openminded appreciation of the environmental qualities of cultural landscapes and a careful treatment of the built environment. In Neuchâtel, it resulted in a new institutional setting in the cooperation between the public and the private sector.

(e) Bridging mountain-lowland relations. In Switzerland, the abandonment of settlement areas is currently not a topic of discussion, probably because a big debate in the 2000s 
resulted in peripheral regions being heard better. However, the gap between the centre and the periphery has widened, as the recent results of federal plebiscites concerning environmental, rural, and agricultural issues show. Examples are the voting on restriction of second homes (2012), law on hunting (2019); responsible multinational companies (2020); initiatives against agricultural water pollution and against pesticides will follow in the next months. Positive examples can be the building blocks for a renewed solidarity-based territorial policy that bridges the gap between metropolitan areas and hinterlands. In this respect, it is helpful that the Canton of Neuchâtel is heterogeneous, including urban, peri-urban, and rural regions as well as lakeside areas and mountain valleys. In this sense, there may be conflicts of interest between different parts of the canton but, because of this diversity, the jurisdiction should be able to (as it is obliged to) minimize them. This statement puts into question recent regional mainstream strategies that demand for regional prosperity a clearly visible homogenous profile and an exaggerated very smallscaled identity.

(f) Stabilizing existing institutions to maintain future options. Mountain areas have structural disadvantages compared to urban core areas, even if they are able (and often do) annoying people in lowland urban areas. Fordist regimes actively tried to counterbalance the disadvantages by trickle-down policies. Under post-Fordist conditions, this method has been called into question, demanding regional efforts to attract people and enterprises. The SI initiatives were an indirect response to these new strategic demands. Nevertheless, these efforts did not fundamentally change the territorial hierarchy or their inferiority, which is not surprising in view of the role of the mountains in the global spatial division of labour [61]. Indeed, a general reversal of existing spatial hierarchies was neither intended nor could be expected due to the limited nature of the initiatives. On the other hand, it can be assumed that, without them, the demographic and economic conditions would have been significantly worse. In the case of the Canton of Neuchâtel, the industrial profile was maintained: the cantonal government and civil society demonstrated their loyalty. Moreover, the regional GDP recently showed a very positive picture: the Jura region was able to keep pace with the rest of Switzerland. Changes in social practices in peripheral areas, even without being transformative, can therefore be named as SI, provided they do not serve as social or greenwashing, intended to conceal the dismantling of the welfare state. Such initiatives demonstrate the vitality and in turn affirm the legitimacy of a holistic regional policy. We should mention that a rising number of adaptive SI might generate a movement with a transformative character.

\section{Concluding Remarks}

SIs are changes in the social practices and processes of a given society. They arise from crises situations, when previous ways of acting are no longer practicable or key actors are blocked (conflict situations). At the time of the assessment, this change must be new and thus forward-looking. That what is new and progressive remains contested: the spatial and temporal frame of reference is debatable and must be agreed upon by discussion for each case. Additionally, what once was an innovation may later turn out to be part of a negative trajectory.

In mountain regions, the triggering problems lie in the loss of significance or functional degradation compared to the lowland metropolitan areas. In the past, mountain regions benefitted from the trickle-down effects of societal progress; today, they have to find their own way by inventing new business models to maintain service quality. In the economic mainstream they are strongly recommended to apply offer-oriented strategies for value adding. Nevertheless, they will rarely be able to change their position in the territorial hierarchy. The main source of success will be if they can generate a part of their own added value in order not to be completely dependent and to maintain goodwill and further support from the richer lowland regions.

Like the triggering problem, the outcomes of an SI are also concrete (e.g., organic beef or vegetables as a new service offered by a newly founded consumer-farmer cooperative). 
The concrete outcomes, however, do not constitute the innovative character of SI, because the new product ideas mostly have already been tried elsewhere (so they actually are copies or "best practices"), and often the immediate entrepreneurial motive is in the foreground. In these cases, one can honestly speak of economic innovations. However, such a cooperative, even if tried out already in a metropolitan area, has a specific progressive impact if applied to a mountain village where people did not cooperate in this way before. Concrete outcomes are important to respond on a specific problem, but what matters in the long term is the intensity of the process and the impact of the SI initiative. The focus of SI research in mountain development should therefore lie on identifying new forms of social agency and institutions with their impacts on spatiality.

Institutional Review Board Statement: The information regarding the two SI initiatives were collected and analyzed within the framework of Horizon 2020 project SIMRA. Data collection and research design complied with the legal guidelines on research ethics as required under rules for receiving EU H2020 funding (Regulation (EU) 1291/2013, 11 December 2013), and the internal arrangements of individual project partners. The ethical clearance procedure is described in the SIMRA Deliverable 5.1 (http:/ / www.simra-h2020.eu/wp-content/uploads/2018/06/SIMRA-D5.1_Case-Study-Protocolsand-Final-Synthetic-Description-for-Each-Case-Study--1.pdf, accessed on 24 March 2021).

Informed Consent Statement: Informed consent was obtained from all subjects involved in the study.

Data Availability Statement: The data that support the findings of this study are available on request from the corresponding author (E.R.) starting from 2023. The data are not publicly available due to conditions associated with their collection (e.g., could compromise the privacy of research participants], in line with ethical clearance obtained. Further details of the case studies are available on the SIMRA project www.site (accessed on 24 March 2021), www.simra-h2020.eu/index.php/ simra-case-studies/ (accessed on 24 March 2021).

Acknowledgments: This paper is based on research done in the framework of the Swiss case studies for SIMRA, a Horizon 2020 European Commission project (Grant Agreement No 677622), and completely financed by the Swiss State Secretariat for Education, Research, and Innovation (SERI); URL: www.simra-h2020.eu (accessed on 30 December 2020). The author also thanks the members of the focus groups and the interviewees in Val Lumnezia/Grisons and Val-de-Travers/Neuchâtel as well as Andrea Koch and Peter Herrmann from the Swiss Working Group for Mountain Regions (SAB) for their fieldwork. Finally, special thanks are due to Valentino Marini Govigli who processed the social network analysis as well as the other quantitative data and prepared the case reports. The paper was substantially ameliorated with the comments of the critical reviewers and especially due to the guest editors, thank you for this.

Conflicts of Interest: The author declares no conflict of interest.

\section{Appendix A}

Table A1. Six types of existing social innovation in the Alps. This is a nonexhaustive classification using known examples of initiatives in the Alps and grouping them according to their main topic. There is no difference between adaptive and transformative social innovation; however, the selection and grouping tries to avoid listing activities that are clearly part of regional marketing or the narratives for a new offer-oriented business model. One can conclude that SI in mountainous areas includes initiatives that impact a societal surplus in that they introduce new practices of interaction between the social actors involved, with the goal of reducing structural asymmetries between centres and periphery and between the groups of actors involved. Pure regional development strategies (primarily measured in terms of regional GDP) should consistently be referred to as economic innovations.

\section{Type [with References]}

Contemporary forms of inherited uses of commons (Allmende/biens communaux) [62-64]

Six Types of Existing Social Innovation in the Alps Examples

Why It Is an SI

Alpine corporations, common municipality work with defined rights and obligations (like repairing watercourses)
As local institutions, they could prevent over- and underuse in territories difficult to cultivate. The challenge is to keep balancing of in- and exclusion of stakeholders for sustainable use. 
Table A1. Cont.

\begin{tabular}{|c|c|c|}
\hline \multicolumn{3}{|c|}{ Six Types of Existing Social Innovation in the Alps } \\
\hline Type [with References] & Examples & Why It Is an SI \\
\hline $\begin{array}{l}\text { New organisational and institutional } \\
\text { arrangements for acquiring work, } \\
\text { production, and jobs [65] }\end{array}$ & $\begin{array}{l}\text { Producer-consumer cooperatives; } \\
\text { contract agriculture; common hotelling } \\
\text { (Alberghi diffusi); commonly organised } \\
\text { coworking residences, e.g., MiaEngiadina }\end{array}$ & $\begin{array}{l}\text { The exchange between lowland and } \\
\text { mountain populations is crucial to avoid } \\
\text { large-scale segregation and deep cultural } \\
\text { cleavages between territories. }\end{array}$ \\
\hline $\begin{array}{l}\text { Collective action with new institutional } \\
\text { arrangements [66-68] }\end{array}$ & Community network Alliance in the Alps & $\begin{array}{c}\text { Getting new knowledge by interregional } \\
\text { and supranational cooperation and } \\
\text { exchange. }\end{array}$ \\
\hline $\begin{array}{l}\text { Corrections of former environmental or } \\
\text { societal malpractices [69] }\end{array}$ & $\begin{array}{l}\text { Pesticide-free municipality of Mals/Val } \\
\text { Venosta/IT; conversion to } 100 \% \text { organic } \\
\text { agriculture in Val Poschiavo/CH }\end{array}$ & $\begin{array}{l}\text { Polluted soils and waters are the most } \\
\text { visible impacts of a liberal, productivist } \\
\text { regime of accumulation. Solidarity } \\
\text { practices to recreate natural resources are } \\
\text { its counterpart. }\end{array}$ \\
\hline $\begin{array}{l}\text { Re-introducing or sustaining of old, } \\
\text { approved techniques and skills [70-72] }\end{array}$ & $\begin{array}{l}\text { New breweries to rebuild a value chain } \\
\text { on barley; reconstructing chestnut forests; } \\
\text { wool processing; cultivation of old plants } \\
\text { and domesticated animals; enlargement } \\
\text { of mountain dairies for urban food } \\
\text { supply; maintenance of drystone walls }\end{array}$ & $\begin{array}{l}\text { In the current productivist strategies, } \\
\text { mountain areas are mainly regarded as } \\
\text { landscapes to be valorised according to } \\
\text { mainstream aesthetics. A more diverse } \\
\text { economic spectrum should aim at } \\
\text { preventing territorial cleavages in wealth } \\
\text { and the overuse of ecologic resources. }\end{array}$ \\
\hline $\begin{array}{c}\text { Civic engagement against isolation, } \\
\text { exclusion, and regional egoism } \\
{[16,73-80]}\end{array}$ & $\begin{array}{l}\text { Welcoming towards migrants and } \\
\text { refugees ("welcoming culture") }\end{array}$ & $\begin{array}{l}\text { The inclusion of incomers raises the } \\
\text { capacities of social interaction; local } \\
\text { communities can benefit as well as } \\
\text { migrants. Respecting human rights is } \\
\text { currently not mainstream but sustainable. }\end{array}$ \\
\hline
\end{tabular}

Table A2. The case study sample in Val Lumnezia.

(A)

\begin{tabular}{|c|c|c|c|c|c|c|c|}
\hline & \multirow[b]{2}{*}{$\begin{array}{c}\text { Tool } 2 \\
\text { Focus Group }\end{array}$} & \multicolumn{2}{|c|}{$\begin{array}{c}\text { Structured and } \\
\text { Semi-Structured Interviews }\end{array}$} & \multicolumn{4}{|c|}{ Structured Interviews } \\
\hline & & $\begin{array}{c}\text { Tool } 7 \\
\text { Internal to } \\
\text { the Social } \\
\text { Innovation }\end{array}$ & $\begin{array}{c}\text { Tool } 8 \\
\text { External } \\
\text { Experts }\end{array}$ & $\begin{array}{l}\text { Tool } 3 \\
\text { Clique }\end{array}$ & $\begin{array}{c}\text { Tool } 7 \\
\text { Internal to } \\
\text { the Social } \\
\text { Innovation }\end{array}$ & $\begin{array}{l}\text { Tool } 8 \\
\text { External } \\
\text { Experts }\end{array}$ & $\begin{array}{c}\text { Tool } 6 \\
\text { Beneficiaries }\end{array}$ \\
\hline Members & - & - & - & 5 & 13 & 2 & $2068^{a}$ \\
\hline $\begin{array}{l}\text { Sampling Re- } \\
\text { quirements }\end{array}$ & - & - & - & $\begin{array}{l}\text { Judgement } \\
\text { sampling }\end{array}$ & Census & $\begin{array}{c}\text { Convenience } \\
\text { sampling }\end{array}$ & $\begin{array}{l}\text { Convenience } \\
\text { sampling }\end{array}$ \\
\hline Sample Size & 7 & 4 & 3 & 1 & 10 & 1 & 6 \\
\hline $\begin{array}{c}\text { Interviewee } \\
\text { Codes }\end{array}$ & $\begin{array}{l}\text { LUM001 } \\
\text { LUM006 } \\
\text { LUM007 } \\
\text { LUM010 } \\
\text { LUM011 } \\
\text { LUM012 } \\
\text { LUM013 }\end{array}$ & $\begin{array}{l}\text { LUM001 } \\
\text { LUM004 } \\
\text { LUM011 } \\
\text { LUM012 }\end{array}$ & $\begin{array}{l}\text { LUM004 }^{c} \\
\text { LUM011 }^{c} \\
\text { LUM012 }^{c}\end{array}$ & LUM001 & $\begin{array}{l}\text { LUM002 } \\
\text { LUM003 } \\
\text { LUM004 } \\
\text { LUM005 } \\
\text { LUM006 } \\
\text { LUM007 } \\
\text { LUM010 } \\
\text { LUM011 } \\
\text { LUM012 } \\
\text { LUM016 }\end{array}$ & LUM001 & $\begin{array}{l}\text { LUM023 } \\
\text { LUM024 } \\
\text { LUM025 } \\
\text { LUM026 } \\
\text { LUM027 } \\
\text { LUM028 }\end{array}$ \\
\hline
\end{tabular}

${ }^{a}$ Inhabitants of Lumnezia Commune (2016). Source: Federal Statistical Office Switzerland. Arealstatistik Schweiz. www.bfs.admin.ch/bfs/ de/home/statistiken/raum-umwelt/bodennutzung-bedeckung/gesamtspektrum-regionalen-stufen/gemeinden.html (accessed on 24 March 2021). ${ }^{b}$ Snowball sampling: the evaluator asked LUM001 to choose six people who benefited from the SI. Those were interviewed. ${ }^{c}$ Interviewed as experts but internal to the Social Innovation. 
Table A2. Cont.

(B)

\begin{tabular}{ccc}
\hline Interviewee Code & Role in the Social Innovation & \multicolumn{1}{c}{ Profile } \\
\hline LUM001 & Innovator & Trade and crafts association \\
\hline LUM002 & Follower & Trade and crafts association \\
\hline LUM003 & Follower & Trade and crafts association \\
\hline LUM004 & Follower & Architect \\
\hline LUM005 & Follower & External consultant \\
\hline LUM006 & Follower & External consultant \\
\hline LUM007 & Follower & Environmental NGO \\
\hline LUM010 & Follower & President of district Lumnezia and village major \\
\hline LUM011 & Follower & Regional and national politician \\
\hline LUM012 & Transformer & Village major and local politician \\
\hline LUM013 & Transformer & Director tourism and tourism consultant \\
\hline LUM016 & Transformer & Regional politician \\
\hline LUM023 & Beneficiary & Village major, farmer \\
\hline LUM024 & Beneficiary & Regional politician \\
\hline LUM025 & Beneficiary & Independent entrepreneur (artisan) \\
\hline LUM026 & Beneficiary & Farmer \\
\hline LUM027 & Beneficiary & Land register administrator \\
\hline LUM028 & Beneficiary & Independent entrepreneur (construction) \\
\hline TOTAL & 18 & \\
\hline & & \\
\hline & & \\
\hline
\end{tabular}

Table A3. The case study sample in Neuchâtel (Canton, Réseau des Fleurons, Val-de-Travers).

(A)

\begin{tabular}{|c|c|c|c|c|c|c|c|}
\hline & \multirow[b]{2}{*}{$\begin{array}{c}\text { Tool } 2 \\
\text { Focus Group }\end{array}$} & \multicolumn{2}{|c|}{$\begin{array}{c}\text { Structured and } \\
\text { Semi-Structured Interviews }\end{array}$} & \multicolumn{4}{|c|}{ Structured Interviews } \\
\hline & & $\begin{array}{c}\text { Tool } 7 \\
\text { Internal to } \\
\text { the Social } \\
\text { Innovation }\end{array}$ & $\begin{array}{c}\text { Tool } 8 \\
\text { External } \\
\text { Experts }\end{array}$ & $\begin{array}{l}\text { Tool } 3 \\
\text { Clique }\end{array}$ & $\begin{array}{c}\text { Tool } 4 \\
\text { Network }\end{array}$ & $\begin{array}{l}\text { Tool } 5 \text { Project } \\
\text { Partners }\end{array}$ & $\begin{array}{c}\text { Tool } 6 \\
\text { Beneficiaries }\end{array}$ \\
\hline Members & - & - & - & $6^{a}$ & $95^{a}$ & $15^{\mathrm{a}}$ & $11898^{b}$ \\
\hline $\begin{array}{l}\text { Sampling Re- } \\
\text { quirements }\end{array}$ & - & - & - & $\begin{array}{l}\text { Convenience } \\
\text { sampling }\end{array}$ & $\begin{array}{l}\text { Convenience } \\
\text { sampling }\end{array}$ & $\begin{array}{l}\text { Convenience } \\
\text { sampling e }\end{array}$ & $\begin{array}{c}\text { Convenience } \\
\text { sampling }\end{array}$ \\
\hline Sample Size & 5 & 2 & 1 & 2 & 4 & 2 & 2 \\
\hline $\begin{array}{l}\text { Interviewee } \\
\text { Codes }\end{array}$ & $\begin{array}{c}\text { FLE001 } \\
\text { FLE003 } \\
\text { FLE004FLE006 } \\
\text { FLE0019 }\end{array}$ & $\begin{array}{l}\text { FLE002 } \\
\text { FLE004 }\end{array}$ & FLE020 & $\begin{array}{l}\text { FLE002 } \\
\text { FLE004 }\end{array}$ & $\begin{array}{l}\text { FLE003 } \\
\text { FLE005 } \\
\text { FLE006 } \\
\text { FLE007 }\end{array}$ & $\begin{array}{l}\text { FLE001 } \\
\text { FLE008 }\end{array}$ & $\begin{array}{l}\text { FLE017 } \\
\text { FLE018 }\end{array}$ \\
\hline
\end{tabular}

\footnotetext{
${ }^{a}$ Estimation. ${ }^{b}$ Inhabitants Val-de-Travers, Les Verrières and La-Côte-aux-Fées (2017). Source: Federal Statistical Office Switzerland. Gemeindeportraits. https://www.bfs.admin.ch/bfs/de/home/statistiken/regionalstatistik/regionale-portraets-kennzahlen/ gemeinden/gemeindeportraets.html (accessed on 24 March 2021) ${ }^{c}$ The evaluator used the information gathered during the focus group to select the key innovators to interview (people knowledgeable about the initiative and with a key role). ${ }^{\mathrm{d}}$ The evaluator used the information gathered during the focus group to select the key informants to interview (people knowledgeable about the initiative and with a key role). ${ }^{\mathrm{e}}$ The evaluator asked the participants of the focus group to select key informants to interview (representatives of different "subgroups" so as to understand different viewpoints). Beneficiaries were selected from names provided by FLE003.
} 
Table A3. Cont.

(B)

\begin{tabular}{ccr}
\hline Interviewee Code & Role in the Social Innovation & Profile \\
\hline FLE001 & Transformer/Project Partner & Politician and part of the administration of Val-de-Travers \\
\hline FLE002 & Innovator & Former chief officer in the cantonal administration \\
\hline FLE003 & Follower & Project manager \\
\hline FLE004 & Innovator & Cantonal executive politician. Main initiator together with FLE002 \\
\hline FLE005 & Follower & Member of a local municipality council \\
\hline FLE006 & Transformer & Member of Réseau des Fleurons, CEO of a manufacturing enterprise \\
\hline FLE007 & Mainstreamer & Administrator of a municipality that did not merge \\
\hline FLE008 & Project Partner & Politician, part of the administration of the merged municipality \\
\hline FLE017 & Beneficiary & Citizen of Val-de-Travers, member of cantonal parliament \\
\hline FLE018 & Beneficiary & Management of enterprise of Réseau des Fleurons \\
\hline FLE019 & Follower / Project Partner & Project manager at RUN \\
\hline FLE020 & Policy Expert & Academic \\
\hline TOTAL & 12 & \\
\hline
\end{tabular}

\section{References}

1. Ravazzoli, E.; Dalla Torre, C.; Da Re, R.; Marini Govigli, V.; Secco, L.; Górriz-Mifsud, E.; Pisani, E.; Barlagne, C.; Baselice, A.; Bengoumi, M.; et al. Can social innovation make a change in European and Mediterranean marginalized areas? Social innovation impact assessment in agriculture, fisheries, forestry, and rural development. Sustainability 2021, 13, 1283. Available online: https: / /www.mdpi.com/2071-1050/13/4/1823 (accessed on 15 March 2021). [CrossRef]

2. Davezies, L. Le Nouvel Égoïsme Territorial. Le Grand Malaise des Nations; Seuil: Paris, France, 2015.

3. Schumpeter, J.A. Capitalism, Socialism and Democracy; Harper: New York, NY, USA, 1975 [1942].

4. Urban, B.; Hobbs, J. Nando's Chilli Sourcing: Innovation for Social Impact; Sage: London, UK, 2015.

5. Yunus, M.; Moingeon, B.; Lehmann-Ortega, L. Building Social Business Models Lessons from the Grameen Experience. Long Range Plan. 2010, 43, 308-325. [CrossRef]

6. Schuler, M.; Perlik, M.; Pasche, N. Non-Urbain, Campagne ou Périphérie—Où se Trouve l'Espace Rural Aujourd'hui? Office fédéral du développement territorial (ARE): Ittigen, Switzerland, 2004.

7. Fujita, M.; Krugman, P.; Venables, A. The Spatial Economy: Cities, Regions and International Trade; MIT Press: Cambridge, MA, USA, 1999.

8. Krugman, P. Geography and Trade; MIT Press: Cambridge, MA, USA, 1991.

9. Sheppard, E. The Spatiality of The Limits to Capital. Antipode 2004, 36. [CrossRef]

10. Manow, P. Die Politische Ökonomie des Populismus (The Political Economy of Populism); Suhrkamp: Berlin, Germany, 2018.

11. Rodríguez-Pose, A. The revenge of the places that don't matter (and what to do about it). Camb. J. Reg. Econ. Soc. 2017, 11, 189-209. [CrossRef]

12. UN Transforming Our World. The 2030 Agenda for Sustainable Development; United Nations: New York, NY, USA, 2015.

13. Hu, X.; Hassink, R. Adaptation, adaptability and regional economic resilience: A conceptual framework. In Handbook on Regional Resilience; Bristow, G., Healy, A., Eds.; Edward Elgar: Cheltenham, UK, 2019; p. 512.

14. Fourny, M.-C. Périphérique, forcément périphérique? La montagne au prisme de l'analyse géographique de l'innovation. In Innovation en Territoire de Montagne le Défi de l'Approche Interdisciplinaire, Montagne et Innovation; Attali, M., Granet-Abisset, A.-M., Dalmasso, A., Eds.; PUG: Grenoble, France, 2014; p. 224.

15. Tschumi, P.; Winiger, A.; Wirth, S.; Mayer, H.; Seidl, I. Wachstumsunabhängigkeit durch Soziale Innovationen? Eine Analyse potenzieller Wachstumswirkungen von Sozialen Innovationen im Schweizer Berggebiet. In Postwachstumsgeographien Raumbezüge Diverser und Alternativer Ökonomien, Sozial- und Kulturgeographie; Lange, B., Hülz, M., Schmid, B., Schulz, C., Eds.; Transcript: Bielefeld, Germany, 2020; Volume 38, p. 456.

16. Perlik, M.; Membretti, A. Migration by Necessity and by Force to Mountain Areas: An Opportunity for Social Innovation. MRD 2018, 38, 250-264. Available online: https://bioone.org/journals/mountain-research-and-development/volume-38/issue-3/ MRD-JOURNAL-D-17-00070.1/Migration-by-Necessity-and-by-Force-to-Mountain-Areas/10.1659/MRD-JOURNAL-D-17-0 0070.1.full (accessed on 15 March 2021). [CrossRef]

17. BEPA, Bureau of European Policy Advisers. Social Innovation: A Decade of Changes; European Commission: Luxembourg, 2014.

18. EC, DG Employment, Social Affairs and Inclusion. Social Economy and Social Entrepreneurship. Social Europe Guide 4; European Commission: Luxembourg, 2013. 
19. EC, DG Research and Innovation Socio-economic Sciences and Humanities. Social Innovation Research in the European Union. Approaches, Findings and Future Directions. Policy Review; European Commission: Brussels, Belgium, 2013.

20. EC, DG Regional and Urban Policy and DG Employment, Social Affairs and Inclusion. Guide to Social Innovation; European Commission: Brussels, Belgium, 2013.

21. Bürgin, R.; Mayer, H. Digital periphery? A community case study of digitalization efforts in Swiss mountain regions. In Smart Village Technology. Concepts and Developments. Modeling and Optimization in Science and Technologies; Patnaik, S., Sen, S., Mahmoud, M.S., Eds.; Springer: Berlin, Germany, 2020; Volume 17, p. 436.

22. Andrew, C.; Klein, J.-L. Social Innovation: What Is It and Why Is It Important to Understand It Better; Collection Etudes théoriques 1003; CRISES: Montréal, QC, Canada, 2010.

23. Avelino, F.; Wittmayer, J.; Pel, B.; Weaver, P.; Dumitru, A.; Haxeltine, A.; Kemp, R.; Jørgensen, M.; Bauler, T.; Ruijsink, S.; et al. Transformative social innovation and (dis)empowerment. Technol. Forecast. Soc. Chang. 2019, 145, 195-206. [CrossRef]

24. Avelino, F.; Dumitru, A.; Cipolla, C.; Kunze, I.; Wittmayer, J. Translocal empowerment in transformative social innovation networks. Eur. Plan. Stud. 2020, 28, 955-977. [CrossRef]

25. Klein, J.-L.; Laville, J.-L.; Moulaert, F. (Eds.) L'Innovation Sociale; ERÈS: Toulouse, France, 2014.

26. Landel, P.-A.; Koop, K.; Senil, N. Quand l'innovation sociale change la dynamique des territoires de montagne. In Montagnes en Mouvements. Dynamiques Territoriales et Innovation Sociale, Montagne et Innovation; Fourny, M.-C., Ed.; PUG: Grenoble, France, 2018; p. 219.

27. Moulaert, F.; Martinelli, F.; Swyngedouw, E.; González, S.G. Towards alternative model(s) of local innovation. Urban Stud. 2005, 42, 1969-1990. [CrossRef]

28. Moulaert, F.; Mehmood, A. Spaces of social innovation. In Handbook of Local and Regional Development; Pike, A., Rodriguez-Pose, A., Tomaney, J., Eds.; Routledge: London, UK, 2011; p. 664.

29. Moulaert, F.; Mehmood, A. Analysing regional development: From territorial innovation to path-dependent geography. In The Elgar Companion to Social Economics; Davis, J.B., Dolfsman, W., Eds.; Edward Elgar: Cheltenham, UK, 2015; p. 682.

30. Moulaert, F.; Sekia, F. Territorial innovation models: A critical survey. Reg. Stud. 2003, 37, 289-302. [CrossRef]

31. Perlik, M. Innovations sociales en montagne: Au-delà de l'ingénierie sociale, une véritable force transformatrice? In Montagnes en Mouvements. Dynamiques Territoriales et Innovation Sociale, Montagne et Innovation; Fourny, M.-C., Ed.; PUG: Grenoble, France, 2018; p. 219.

32. MacCallum, D.; Vicari Haddock, S.; Moulaert, F. (Eds.) Social Innovation and Territorial Development; Routledge: London, UK, 2009.

33. Swyngedouw, E. Civil Society, Governmentality and the Contradictions of Governance-beyond-the-State: The Janus-face of Social Innovation. In Social Innovation and Territorial Development; Maccallum, D., Vicari Haddock, S., Eds.; Routledge: London, UK, 2009; p. 188.

34. Swyngedouw, E. From Disruption to Transformation: Politicisation at a Distance from the State. Antipode 2020, 53, 486-496. [CrossRef]

35. TRANSIT (Transformative Social Innovation Theory). Available online: http://www.transitsocialinnovation.eu/briefs (accessed on 15 March 2021).

36. Van den Broeck, P.; Mehmood, A.; Paidakaki, A.; Parra, C. (Eds.) Social Innovation as Political Transformation. Thoughts for a Better World; Edward Elgar: Cheltenham, UK, 2019.

37. Secco, L.; Pisani, E.; Da Re, R.; Rogelja, T.; Burlando, C.; Vicentini, K.; Pettenella, D.; Masiero, M.; Miller, D.; Nijnjk, M. Towards a method of evaluating social innovation in forest-dependent rural communities. First suggestions from a science-stakeholder collaboration. For. Policy Econ. 2019, 104, 9-22. [CrossRef]

38. Perlik, M.; Wissen, U.; Schuler, M.; Hofschreuder, J.; Jarne, A.; Keiner, M.; Cavens, D.; Schmid, W.A. Szenarien für die nachhaltige Siedlungs- und Infrastrukturentwicklung in der Schweiz (2005-2030). Report for the Swiss National Science Foundation (SNSF). In The Framework of National Research Programme 54 "Sustainable Development of the Built Environment"; ETHZ: Zurich, Switzerland, 2008.

39. Schuler, M.; Perlik, M. Regionale Disparitäten. In Schweiz-Geographie, Geschichte, Wirtschaft, Politik; Schneider-Sliwa, R., Ed.; WBG: Darmstadt, Germany, 2011; p. 228.

40. Stucki, E.W.; Roque, O.; Schuler, M.; Perlik, M. Contents and Impacts of Mountain Policies, Switzerland. National Report for the Study Analysis of Mountain Areas in the European Union and in the Applicant Countries; Federal Department of Economic Affairs (seco): Berne, Switzerland, 2004.

41. Diener, R.; Herzog, J.; Meili, M.; de Meuron, P.; Schmid, C. Switzerland: An Urban Portrait; ETH: Zurich, Switzerland; Birkhäuser: Basel, Switzerland, 2006.

42. Crevoisier, O.; Jeannerat, H.; Scherer, R.; Zumbusch, K. Neue Regionalpolitik und Privatwirtschaftliche Initiative. Final Report; Université de Neuchâtel: Neuchatel, Switzerland; Universität St. Gallen: St. Gallen, Switzerland, 2011.

43. Expertenkommission "Überprüfung und Neukonzeption der Regionalpolitik". Neue Regionalpolitik (NRP). Final Report; Federal Department of Economic Affairs (seco): Berne, Switzerland, 2003.

44. Schweizerischer Bundesrat. Botschaft über die Neue Regionalpolitik (NRP) vom 16. November 2005. Available online: https: / / www.fedlex.admin.ch/eli/fga/2006/7/ de (accessed on 15 March 2021).

45. Hadjimichalis, C. The End of Third Italy As We Knew It? Antipode 2006, 38, 82-106. [CrossRef]

46. ARE. Projet de Territoire Suisse; ARE: Berne, Switzerland, 2011. 
47. Cavelti, G.; Kopainsky, B.; Strategien zum Umgang mit potenzialarmen Räumen. Erarbeitet am Beispiel der Kantone Graubünden und Uri (Bericht Graubünden). 2008. Available online: https:/ / regiosuisse.ch/sites/default/files/2016-08/studie-potenzialarmeraeume.pdf (accessed on 15 March 2021).

48. Kopainsky, B.; Cavelti, G.; Giuliani, G. Umgang mit schwachen Räumen. Instrumente und Erfahrungen in den Mitgliedsländern der Arbeitsgemeinschaft Alpenländer Arge Alp. 2007. Available online: https://flurygiuliani.files.wordpress.com/2015/06/k2 -potenzialarme-rc3a4ume.pdf (accessed on 15 March 2021).

49. Meier, R.; SAB. Groupement suisse pour les regions de montagne Angepasster Tourismus—Entwicklung und Aussichten für das Oberlugnez, Kanton Graubünden. In Schriftenreihe der SAB 122; SAB: Berne, Switzerland, 1986.

50. SAB, Groupement suisse pour les régions de montagne. Les Régions de Montagne Suisses. Faits et chiffres. Several Years. Available online: www.sab.ch/fileadmin/user_upload/customers/sab/Dokumente/Publikationen_SAB/Schweizer_Berggebiet_ 2016_Internet.pdf (accessed on 15 March 2021).

51. SAB, Groupement suisse pour les régions de montagne. Potenzialarme Räume: Analyse von Fallbeispielen; SAB: Berne, Switzerland, 2013.

52. Marini Govigli, V.; Perlik, M.; Herrmann, P. Analytical Case Studies (Case Study Type A) Pro Val Lumnezia-Surselva, Canton of Grisons/Switzerland (SAB-UNIBE). Report 5.4b—Social Innovation in Marginalised Rural Areas (SIMRA). 2019. Available online: https://www.researchgate.net/publication/350072616_Analytical_Case_Studies_Case_Study_Type_A_Pro_Val_Lumnezia_-_ Surselva_Canton_of_GrisonsSwitzerland_UNIBECDE_SAB_Report_54b_-_Social_Innovation_in_Marginalised_Rural_Areas_ SIMRA (accessed on 15 March 2021).

53. Marini Govigli, V.; Perlik, M.; Koch, A. Analytical-Informational Case Studies (Case Study Type B) Réseau Urbain Neuchâtelois (UNIBE/CDE \& SAB). Report 5.41. Social Innovation in Marginalised Rural Areas (SIMRA). 2019. Available online: https://www.researchgate.net/publication/350074362_Analytical__Informational_Case_Studies_Case_Study_Type_ B_Reseau_Urbain_Neuchatelois_SAB-UNIBE_Report_541_-_Social_Innovation_in_Marginalised_Rural_Areas_SIMRA_pp_68 (accessed on 15 March 2021).

54. Kluvánková, T.; Nijnik, M.; Spacek, M.; Sarkki, S.; Perlik, M.; Lukesch, R.; Melnykovych, M.; Valero, D.; Brnkal’áková, S. Social innovation for sustainability transformation and its diverging development paths in marginalised rural areas. Soc. Rural. 2021. [CrossRef]

55. Lukesch, R.; Ludvig, A.; Slee, B.; Weiss, G.; Živojinović, I. Social Innovation, Societal Change, and the Role of Policies. Sustainability 2020, 12, 7407. Available online: https:/ / www.mdpi.com/2071-1050/12/18/7407 (accessed on 15 March 2021). [CrossRef]

56. Agnew, J. The territorial trap: The geographical assumptions of international relations theory. Rev. Int. Political Econ. 1994, 1, 53-80. [CrossRef]

57. Debarbieux, B.; Balsiger, J. Sustainable development and the concept of scale. In The Elgar Companion to Geography, Transdisciplinarity and Sustainability; Sarmiento, F.O., Frolich, L.M., Eds.; Edward Elgar: Cheltenham, UK, 2020; p. 448.

58. Piketty, T. Capital in the Twenty-First Century; Belknap Press: Cambridge, MA, USA, 2014.

59. Piketty, T. Capital and Ideology; HUP: Cambridge, MA, USA, 2020.

60. Crevoisier, O.; Corpataux, J.; Thierstein, A. Intégration Monétaire et Régions: Des Gagnants et des Perdants; Harmattan: Paris, France, 2001.

61. Perlik, M. The Spatial and economic transformation of mountain regions. Landscapes as commodities. In Routledge Advances in Regional Economics, Science and Policy; Routledge: London, UK, 2019.

62. Haller, T.; Breu, T.; De Moor, T.; Rohr, C.; Znoj, H. (Eds.) The Commons in a Global World book. Global Connections and Local Responses; Routledge: London, UK, 2019.

63. Niederer, A. Alpine Alltagskultur Zwischen Beharrung und Wandel. Ausgewählte Arbeiten aus den Jahren 1956-1991; Anderegg, K., Bätzing, W., Eds.; Haupt: Berne, Switzerland, 1993.

64. Ostrom, E. Governing the Commons: The Evolution of Institutions for Collective Action; CUP: Cambridge, MA, USA, 1990.

65. Rist, S.; Bürgi Bonanomi, E.; Giger, M.; Hett, C.; Scharrer, B.; Jacobi, J.; Lannen, A. Variety is the source of life: Agrobiodiversity benefits, challenges, and needs. In Swiss Academies Factsheets 15; Swiss Academy of Science: Berne, Switzerland, 2020.

66. Balsiger, J. The Impact of Ecoregional Mobilization on Mountain Policies in the Swiss Alps and California's Sierra Nevada. J. Alp. Res. 2009, 97. Available online: https://journals.openedition.org/rga/876 (accessed on 15 March 2021). [CrossRef]

67. Debarbieux, B. Preface: Mountain regions as referents for collective action. J. Alp. Res. 2009, 97. Available online: https: //journals.openedition.org/rga/855 (accessed on 15 March 2021).

68. Rudaz, G.; Territorial redefinition and the governance of mountain regions. J. Alp. Res. 2009, 97. Available online: https: //journals.openedition.org/rga/866 (accessed on 15 March 2021).

69. Wysling, A. Ein Dorf kämpft gegen die Agrochemie. Mals im Südtirol-die erste pestizidfreie Gemeinde Europas. NZZ (Neue Zürcher Zeitung), 3 October 2015; 11.

70. Grison, J.-B.; Landel, P.-A. The Wool-Processing Industry in an Era of Social Innovation. How Has the Situation Changed in the Massif Central (France)? J. Alp. Res. 2019, 107. Available online: https://journals.openedition.org/rga/5982 (accessed on 15 March 2021). [CrossRef]

71. Institutionelle Regime für nachhaltige Landschaftsentwicklung. Régimes Institutionnels pour le Développement Durable du Paysage; Rodewald, R., Knoepfel, P., Eds.; Ecologie \& Société; Rüegger: Zurich, Switzerland, 2005; Volume 20. 
72. Varotto, M.; Bonardi, L.; Tarolli, P. (Eds.) World Terraced Landscapes: History, Environment, Quality of Life; Springer: Cham, Switzerland, 2019.

73. Cretton, V.; The Mountain, Emblem of the Paradox of the Integration of Asylum Seekers in Switzerland. J. Alp. Res. 2020, 108. Available online: https://journals.openedition.org/rga/7027 (accessed on 15 March 2021).

74. ForAlps (Foreign Immigration in the Alps). Available online: www.foralps.eu (accessed on 10 November 2019).

75. Galera, G.; Giannetto, L.; Membretti, A.; Noya, A. Integration of migrants, refugees and asylum seekers in remote areas with declining populations. In OECD Local Economic and Employment Development (LEED) Working Papers, 2018/03; OECD: Paris, France, 2018.

76. Graf, F. A Life Here and There: First-generation Migrants in the Grison Alps. In Alpine Refugees-Immigration at the Core of Europe; Perlik, M., Galera, G., Machold, I., Membretti, A., Eds.; CSP: Cambridge, MA, USA, 2019; p. 303.

77. Gretter, A.; Machold, I.; Membretti, A.; Dax, T. Pathways of Immigration in the Alps and Carpathians: Social Innovation and the Creation of a Welcoming Culture. Mt. Res. Dev. 2017, 37, 396-405. Available online: https://bioone.org/journals/mountainresearch-and-development/volume-37/issue-4/MRD-JOURNAL-D-17-00031.1/Pathways-of-Immigration-in-the-Alps-andCarpathians--Social/10.1659/MRD-JOURNAL-D-17-00031.1.full (accessed on 15 March 2021). [CrossRef]

78. MATILDE (Migration Impact Assessment to Enhance Integration and Local Development in European Rural and Mountain Areas). A Horizon 2020 Project. Available online: https:/ / matilde-migration.eu/ (accessed on 1 December 2020).

79. PlurAlps (Enhancing Capacities for a Pluralistic Alpine Space). An Alpine Space Project. Available online: https://www.alpinespace.eu/projects/pluralps/en/home (accessed on 1 December 2020).

80. Semprebon, M. Promoting an Integrated Local Welfare System in an "Unwelcoming" Mountain Area: The Reception of Forced Migrants in Val Camonica. In Alpine Refugees-Immigration at the Core of Europe; Perlik, M., Galera, G., Machold, I., Membretti, A., Eds.; CSP: Cambridge, MA, USA, 2019; p. 303. 